\title{
The family Carditidae (Bivalvia) in the early Danian of Patagonia (Argentina)
}

\author{
Damián E. Pérez and Claudia J. del Río \\ Museo Argentino de Ciencias Naturales Bernardino Rivadavia, División Paleoinvertebrados, Av. Ángel Gallardo 470 (C1405DJR), Buenos Aires, \\ Argentina. 〈trophon@gmail.com〉; 〈claudiajdelrio@gmail.com〉
}

\begin{abstract}
The first systematic analysis of the Danian carditids of Patagonia is presented, which includes four genera- one new genus and the first records of three other genera in South America. They consist of Claibornicardia paleopatagonica (Ihering, 1903), a widely distributed species occuring in the Jagüel, Roca and Salamanca formations (Neuquén, Río Negro and Chubut Provinces); Rotundicardia Heaslip, 1968, represented by the new species R. mariobrosorum n. sp., which is restricted to the Roca Formation (Río Negro Province); Cardites feruglioi (Petersen, 1846) (Roca and Lefipán formations, Río Negro and Chubut Provinces); and by Kalelia new genus, which includes K. burmeisteri (Böhm, 1903) from the Salamanca and Roca formations (Río Negro and Chubut Provinces), which is related to the Paris Basin species K. multicostata (Lamarck, 1806) n. comb. and K. pectuncularis (Lamarck, 1806) n. comb. 'Venericardia' iheringi (Böhm, 1903), a species known only from internal molds, is described and regarded as a carditid with uncertain affinities. The presence of Claibornicardia, Rotundicardia, and Cardites in Patagonia constitutes the most ancient record of these genera and confirms biogeographical connections previously established between the Danian Argentinian and North American/European fossil faunas.
\end{abstract}

\section{Introduction}

The family Carditidae Férussac, 1822 comprises a large group of heterodont bivalves worldwide, ranging from Devonian to modern times (Chavan, 1969), becoming a highly diversified group in the Eocene of the Gulf Coastal Plain (GCP) of the U.S.A. (Gardner and Bowles, 1939; Heaslip, 1968), and the Paris Basin (Cossmann and Pissarro, 1904; Cossmann and Peyrot, 1912). The Carditidae are placed in the recently defined clade Archiheterodonta, the sister group of true heterodont bivalves (Euheterodonta) (Giribet, 2008). The carditids constitute an important component of this group, in which systematic and phylogenetic relationships are poorly understood (Giribet, 2008; González and Giribet, 2014). The generic placement of carditids is complicated. For example, the genus Venericardia Lamarck, 1801 is a highly diversified taxon represented by more than 50 recent and several fossil species included in numerous subgenera. The assignments of recent species to this genus is uncertain and many of these assignments, both fossil and recent, were never reviewed. Therefore, the generic diversity of carditids is underestimated (Huber, 2010).

Only a few species of Paleocene carditids have been recorded in the Bassin de Brive and Sables de Bracheux (France; Cossmann and Pisarro, 1904; Lhomme and Freneix, 1993), in the Wangaloa Formation (New Zealand; Beu and Maxwell, 1990; Stilwell, 2003), in the Pebble Point Formation (Australia; Darragh, 1994), in the Kincaid, Lodo, and Clayton formations (USA; Gardner, 1935; Moore, 1992; Cope et al., 2005), and in the Soldado Formation (Trinidad and Tobago; Rutsch, 1943).
Although an abundant and greatly diversified group in Patagonia, Cenozoic carditids, and particularly those of Danian age, remain almost completely unstudied. Initial work was conducted by Burckhardt $(1900,1902)$ who, based on internal casts, recognized the presence of the Brazilian Paleocene species Cardita morganiana Rathbun, 1875 in the southern latitudes of Patagonia. Subsequent studies carried out by Böhm (1903), Ihering (1903, 1907), Feruglio (1936), Petersen (1946), and Masiuk (1967) increased the number of Danian species endemic to Patagonia to four, all of which were included in the Eocene European genus Venericardia. More recently, and without any justification for the generic placement, the genus Glyptoactis Stewart, 1930 was proposed by Rodríguez et al. (1995) for material from the Coli Toro Plateau area (Río Negro Province). Scasso et al. (2012) mentioned carditids from the Lefipán Formation (Chubut Province), placing them in the genus Pacificor Verastegui, 1953. A systematic revision of these species has not been carried out, so the relationships of this carditid fauna have remained poorly known.

Carditids recently collected in new localities allow the first systematic revision of the group in Patagonia. This is essential for a better understanding of the evolution of the family Carditidae and contributes to increasing the knowledge of the composition of the Danian assemblages of the southern hemisphere.

\section{Geological setting}

Carditids included in the present analysis were recovered from the Danian marine rocks of the Neuquina, Cañadón Asfalto and 
San Jorge basins (Fig. 1.1) where they are common to abundant components of the faunas that inhabited the Rocaguelian and Salamancan bioprovinces (del Río and Martínez, 2015). The fossiliferous stratigraphic sequences of each of these basins have been summarized by del Río et al. (2007, 2011), del Río (2012), and del Río and Martínez (2015). An accurate stratigraphic scheme for the type area of the Roca Formation was provided by del Río et al. (2011) based on calcareous nannoplankton assemblages associated with the molluscs.

Neuquina Basin.-Carditids included in the present paper come from the Roca Formation exposed at Malargüe (Mendoza Province), Cerros Bayos (La Pampa Province) and the surroundings of the city of General Roca (Río Negro Province), and from the Jagüel Formation exposed at Opaso section (Neuquén Province) (Fig. 1.1, 1.2).

Fossils from General Roca have been recorded in the NP1NP4 biozones recognized in Cantera Cholino, Picada Sísmica and Zanjón Roca sections, where abundant internal molds of carditids have been collected (Fig. 2.1-2.3). Assemblages constitute parauthochtonous accumulations. Carditids are associated with dense concentrations of the gastropod Rostellaria rothi Ihering, 1903 and the oyster Cubistostrea ameghinoi (Ihering, 1902) (Cantera Cholino samples 15 and 17, respectively), and of turritellids in Picada Sísmica, where the carditids are found alone with the infaunal soft-bottom dewelling bivalves Neilo sp. and Dosinia burckhardti Ihering, 1907 (del Río et al., 2011).

Carditids are rare at Cerro Bayos, where only one species has been found. Material comes from basal (CB31 and CB32 samples) and uppermost limestones (CB47 samples) of the Roca
Formation where the NP1 and NP3 biozones are identified, respectively (Fig. 2.8). In the basal limestones, fossils are infrequent, carditids are rare, and the bivalves Pycnodonte (Phygrea) burckhardti (Böhm, 1903), Delectopecten, Parvamussium, and unidentified veneroids dominate the fauna. In contrast, horizons at the top of the section are highly fossiliferous, and comprise up to $8 \mathrm{~m}$ thick amalgamated yellowish, massive limestones with a dense accumulation of Cubitostrea ameghinoi, Turritella spp. and subordinate representatives of the carditids and the bivalves Gryphaostrea callophyla (Thering, 1903) and Jupiteria sp. (del Río et al., 2007).

Strata exposed in the vicinities of Puesto Pircala (Mendoza Province, Neuquina Basin) record the only Maastrichtian carditids mentioned in this paper and only a brief explanation will be provided herein (Fig. 2.9). These exposures comprise $30 \mathrm{~m}$ of intercalation green and white mudstones and highly fossiliferous yellowish limestones with the gastropod 'Turritella' sp., and the bivalves Musculus aprilis (Feruglio, 1935), Ambigostrea clarae (Ihering, 1907), Amphidonte mendozana Ihering, 1907, Pinna sp., Camptonectes sp., Acesta sp., Yoldia? sp., Paraesa? sp. and Pterotrigonia sp.

Cañadón Asfalto Basin.-Carditids are very abundant in the Roca Formation exposed in the Bajo de Colitoro Grande, Bajo Hondo, and Bajo Lenza Niyeu (Río Negro Province) (Fig. 1.3). However, while they are rare components of the fauna in the uppermost horizons of the Lefipán Formation at the middle Chubut River, they are common bivalves in the Salamanca Formation exposed in Sierra de los Guanacos area (Chubut Province).

Fossiliferous horizons in the Bajo Hondo and Bajo Lenza Niyeu are exposed at Puesto Nahuel Cheo and Puesto Carmelo

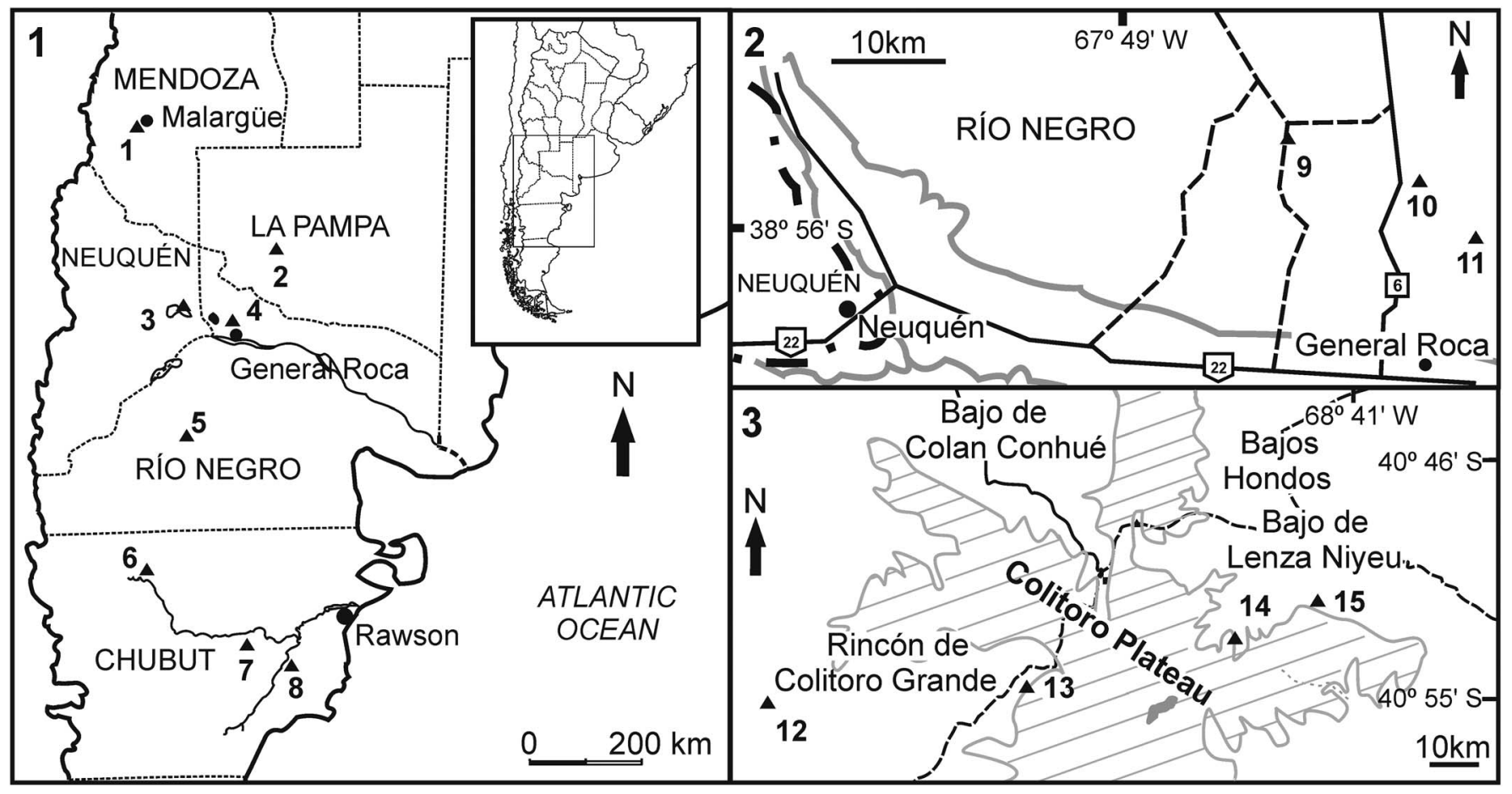

Figure 1. (1) General placement of study areas. (2) Fossiliferous sites at General Roca. (3) Fossiliferous sites at Colitoro Plateau. $1=$ Puesto Pircala, $2=$ Cerros Bayos, $3=$ Opaso, $4=$ General Roca area, $5=$ Coli Toro Plateau area, $6=$ Puesto Crettón, $7=$ Puesto Ramírez, $8=$ Puesto Álvarez, $9=$ Cantera Cholino, 10 = Picada Sísmica, 11 = Zanjón Roca, 12 = Cerro Tiltilco, 13 = Puesto Nancucheo, 14 = Puesto Nahuel Cheo, $15=$ Puesto Carmelo Ibañez; (2) and (3) modified from del Río, 2012. 

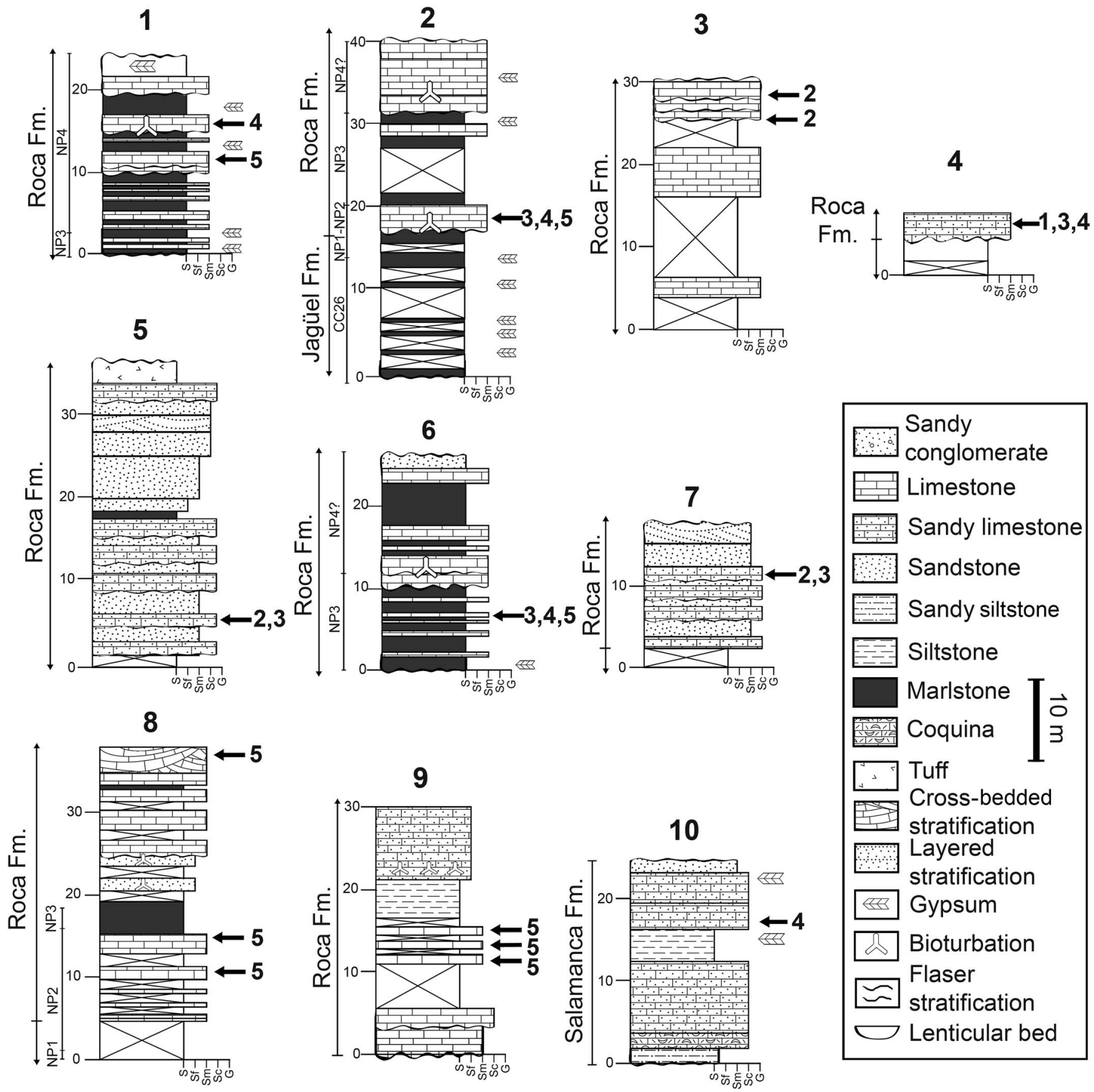

Figure 2. Lithological sections. (1) Cantera Cholino. (2) Zanjón Roca. (3) Puesto Ñancucheo. (4) Cerro Tiltilco. (5) Puesto Carmelo Ibañez. (6) Picada Sísmica. (7) Puesto Nahuel Cheo. (8) Cerros Bayos. (9) Puesto Pircala. (10) Puesto Álvarez, $1=$ Claibornicardia paleopatagonica, $2=$ Rotundicardia mariobrosorum n. sp., 3 = Cardites feruglioi, 4 = Kalelia burmeisteri, 5 = 'Venericardia' iheringi; (1, 2, 4-7) after del Río, 2012; (8) after del Río et al., 2007; (10) after Masiuk, 1967.

Ibañez sections (Fig. 2.5, 2.6). Here, carditids come from hard, thin, pinkish massive grainstones, constituted by amalgamated, multi-event shell beds with internal discontinuities. Cardites feruglioi (Petersen, 1946) and a new species of Rotundicardia (Heaslip, 1968) herein described are commonly associated with dense concentrations of Pycnodonte (Phygraea) sarmientoi Casadío, 1998, and Ostrea neuquena Ihering, 1907 or Turritella malaspina Ihering, 1903. In both cases a rich gastropod fauna is represented by Tejonia tapiae (Feruglio, 1935), Microfulgur concheyroae del Río, 2012, Heteroterma carmeloi del Río, 2012, Rocalaria alani del Río, 2012, Cavoscala sp., Gyroscala daniana del Río, 2012, Sulcobuccinum prominentum del Río, 2012, Austrophaera patagonica (Feruglio, 1936) and by the echinoid Cidarina lenzaniyeuensis del Río, 2012 (del Río, 2012).

Carditids from Bajo del Colitoro Grande come from Cerro Tiltilco and Puesto Nancucheo sections where the uppermost horizons (Fig. 2.4, 2.7), consisting of thick ochreous and whitish 
massive coquinas, yield Claibornicardia paleopatagonica (Ihering, 1903), R. mariobrosorum n. sp., C. feruglioi, and Kalelia burmeisteri (Böhm, 1903). Associated with the carditids are the bivalves Glycymeris feruglioi Celeste, 1940, Ostrea neuquena Ihering, 1907, Panopea spp., and the gastropods Tejonia tapiae (Feruglio, 1935), Priscofiscus cf. P. gracilis (Wilckens, 1905), Sulcobuccinum prominentum del Río, 2012, and Austrophaera patagonica (Feruglio, 1936) (del Río, 2012).

The Salamanca Formation exposed in the surroundings of Sierra de los Guanacos (Fig. 1.1) consists of an intercalation of siltstones, sandstones and coquinas with a poorly diversified fauna (Chebli and Serraioto, 1974) with abundant representatives of C. paleopatagonica associated with the bivalves Nucula pervicax Feruglio, 1936, Ostrea neuquena, Bathytormus chubutensis (Feruglio, 1936), and the gastropods 'Turritella' ameghinoi Ihering, 1903, Darwinices claudiae Griffin and Pastorino, 2013, Pseudamaura dubia (Petersen, 1946), 'Cominella iheringi' Feruglio, 1936, Austrophaera patagonica (Feruglio, 1936), Gyroscala daniana del Río, 2012, Turritella malaspina Ihering, 1903 (del Río and Martínez, 2015).

San Jorge Basin.-The studied material was recorded by C. Ameghino from Río Chico, in an area supposedly situated $50 \mathrm{~km}$ south of Puesto Alvarez (Fig. 2.10) (Chubut Province). This section was assigned to the Salamanca Formation and consists of an intercalation of gray or yellow calcareous sandstones with siltstones and whitish coquinas. The species $K$. burmeisteri is associated with the bivalves Glycymeris feruglioi, Panopea thomasi Ihering, 1914, and the gastropods Turritella aff. T. soaresana Hartt in White, 1887, Polinices sp., Arrhoges sp. and Cimomia camachoi Masiuk, 1967.

\section{Materials and methods}

Measurements of carditid shells include lenght and height and follows Heaslip (1968). Specimens were whitened using magnesium oxide before photography. Repositories are listed below.

Repositories and institutional abbreviations.-MACN-Pi and CIRGEO-PI, Museo Argentino de Ciencias Naturales 'Bernardino Rivadavia,' División Paleoinvertebrados, Buenos Aires; CPBA, Cátedra de Paleontología of the Universidad de Buenos Aires, Buenos Aires; MLP, Museo de La Plata, La Plata; GHUNLPam, Facultad de Ciencias Exactas y Naturales of Universidad de La Pampa, Santa Rosa; MHNSR. Pi, Museo de Historia Natural of San Rafael, San Rafael; SGN, Servicio Geológico Minero of Argentina, Buenos Aires; MNHM, Muséum National d'Histoire Naturelle of Paris, France; GMNH, Muséum d'Histoire Naturelle de Genève, Switzerland.

\section{Systematic paleontology}

Morphological terminology agrees with Heaslip (1968), who described the tripartite (='fasciculate' for Maxwell, 1969) sculpture as radiating costae with a central rib flanked by paracostal ones on each side (Heaslip, 1968, text-fig. 4.D), and used the term 'funginated' for the closely placed flaring scales, resembling bracket fungi, placed on central ribs of Rotundicardia Heaslip, 1968.
Terms such as 'planicostates' and 'alticostates' will be used with the phylogenetical meaning proposed by Gardner and Bowles (1939) and Heaslip (1968), who properly described and illustrated them. Planicostates include a lineage of carditid bivalves with large shells, flat and smooth radial ribs, and long cardinal teeth, and alticostates refer to species with small valves, tripartited and sculptured radial ribs, and short cardinal teeth.

\section{Order Archiheterodonta Giribet, 2008 \\ Family Carditidae Férussac, 1822}

Remarks.-The systematics of carditids is complex because there is no consensus about the distinction among genera and subgenera. On one hand, for some authors, the family includes a few genera (Venericardia Lamarck, 1801 and Cardita Bruguière, 1792) with a large number of subgenera (e.g., Megacardita Sacco, 1899; Venericor Stewart, 1930; or Claibornicardia Stenzel and Krause, 1957). Other authors treat some of these subgenera as genera (for a comparison, see Sacco, 1899; Dall, 1903; Chavan, 1969; Moore, 1992; McClure and Lockwood, 2015). The use of subgenera implies close phylogenetic relationships, most of which are poorly understood at present. Therefore, until a complete quantitative phylogenetic study of the family is performed, we consider all carditid genera or subgenera previously proposed to have generic status, thereby discarding all phylogenetic inferences. McClure and Lockwood (2015) proposed that Claibornicardia and Rotundicardia are possible paraphyletic genera based on a phylogenetic study of some GCP carditid species. Because they included relatively few species of both taxa in their analysis, we prefer to keep the monophyletic status until a complete revision is performed.

Chavan (1969) outlined a subfamiliar classification for the Carditidae on the basis of taxonomic criteria. He recognized seven subfamilies, six newly introduced by him: Carditinae, Carditamerinae, Miodomeridinae, Palaeocarditinae, Venericardiinae, Carditesinae, and the previously proposed Thecaliinae Dall, 1903, based mainly on shell shape and hinge morphology. Members of the planicostates and alticostates were indistinctively included in Carditamerinae, Venericardiinae, or Carditesinae by Chavan (1969). In this paper, we reject the subfamiliar classification proposed by Chavan (1969) because his scheme ignored the phylogenetic proposals of other authors (Gardner and Bowles, 1939; Heaslip, 1968), as indicated by the analysis of Pérez and del Río (2016), and prefer these proposals instead.

\section{Genus Claibornicardia Stenzel and Krause, 1957}

Type species.-Cardita alticostata Conrad, 1833 (by original designation). Gosport Sand, McBean and Black Mingo formations, early-middle Eocene of Alabama, United States of America (USA).

Diagnosis.-Carditid with a highly convex shell and an elongated subrectangular outline, posterior area defined by a change in the convexity. Ventral margin of right hinge sinuous. Right anterior tooth thin dorsally or anteriorlly placed to the anterior socket for the left anterior tooth, left anterior tooth broad and triangular. External sculpture of 28-33 tripartite 
radial ribs covered with nodes. Nodes and paracostal ribs suppressed in advanced members of the genus (modified from Heaslip, 1968, p. 98).

Remarks.-The genus Claibornicardia was erected by Stenzel and Krause in Stenzel and Krause, 1957 to include few carditids from the middle Eocene of the GCP geological province (C. alticostata [Conrad, 1833], C. complexicostata [Meyer and Aldrich, 1886], C. nasuta [Dall, 1890], C. sillimani [Lea, 1833], and $C$. trapaquara [Harris, 1895]) and $C$. acuticostata (Lamarck, 1806) from the Eocene of the Paris Basin (France). According to Stenzel and Krause (1957), the key characters of the genus are the elongate-rectangular outline with a faint posterior area, and the development of tripartite radial ribs.

Heaslip (1968) reviewed the genus, and extended its stratigraphic range in the southeastern region of the USA from the early Eocene to the middle Oligocene with the addition of several new species (C. blandingi [Conrad, 1830]; C. coloradonis [Harris, 1919]; C. linguinodifera Heaslip, 1968; C. natchitoches [Harris, 1919]; C. perantiqua [Conrad, 1865]; and C. trapaquaroides Heaslip, 1968), and synonymized $C$. sillimani with $C$. alticostata, stating that it is a case of sexual dimorphism. All American species are characterized by variable outlines, with diverse degrees of elongation and posterior margin acumination ( $C$. nasuta, $C$. trapaquara, and C. trapaquaroides) and/or ventral margin acumination (C. blandingi, C. complexicostata, and C. perantiqua). Particularly, $C$. alticostata shows strong morphological variation (as shown by Heaslip, 1968, pl. 26, figs. 6-11). Cases of allometric growth are recognized within carditids (Stanley, 1972), where the shell outlines can vary throughout ontogeny. Combining allometry with sexual dimorphism and the wide geographical distribution of certain species (e.g., C. alticostata), it is possible that the true intraspecific variation of Claibornicardia is misunderstood and some proposed American species are part of the variation of other species.

Moore (1992) included within Claibornicardia four species from California and Baja California: C. keenae (Verastegui, 1953) (late Paleocene), C. domenginica (Vokes, 1939), C. marksi (Verastegui, 1953), and C. sandiegoensis (Hanna, 1927), the last three all being Eocene. These taxa have less elongate outlines and more convex shells than the eastern American species, but have the characteristic tripartite radial ornamentation.

Claibornicardia aalterensis Vervoenen and van Nieulande, 2010, C. asperrima (Wood, 1861), C. carinata (Sowerby, 1821), and $C$. obovata (Wood, 1861), from the Eocene of England, France, and Belgium, also have been placed within Claibornicardia (Pacaud and Le Renard, 1995; Tracey et al., 1996; Vervoenen and van Nieulande, 2010). These species, together with $C$. acuticostata, should potentially be assigned to a different genus converging with the American species, because they have less elongated outlines with a less well defined posterior area and a fewer radial ribs. There are other records from the Eocene of Colombia and Jamaica that are doubtfully assigned to C. alticostata because they are based on incomplete specimens in which the diagnostic characters cannot be recognized (Anderson, 1928; Cox, 1941). Kafanov et al. (2001) recorded C. keenae from the late Paleocene Getkilninskaya Formation (Kamchatka, Russia; Kafanov and Ogasawara, 2006). This record, together with $C$. keenae from the late Paleocene Lodo Formation
(California, USA, Johnson and Graham, 2007), are the most ancient records known for the genus Claibornicardia.

\section{Claibornicardia paleopatagonica (Ihering 1903)}

Figure 3.1, 3.2, 3.4, 3.5

1903 Cardita paleopatagonica Ihering, p. 215, pl. 2, fig. 12.

1907 Venericardia paleopatagonica (Ihering); Ihering, p. 47.

1914 Venericardia paleopatagonica (Ihering); Ihering, p. 44.

1936 Venericardia paleopatagonica (Ihering); Feruglio, p. 232, pl. 23, figs. 28, 29.

1938b Venericardia paleopatagonica (Ihering); Fossa Mancini, p. 261.

1977 Venericardia camachoi Vigilante, p. 20, pl. 1, fig. 6.

1987 Venericardia paleopatagonica (Ihering); Farinati et al., p. 154 , pl. 1, fig. 5 .

1995 Glyptoactis paleopatagonica (Ihering); Rodríguez et al., p. 243, pl. 2, fig. G.

1995 Glyptoactis sp. (Ihering); Rodríguez et al., p. 243, pl. 2, fig. H.

1996 Cardita paleopatagonica Ihering; Parodiz, p. 246.

2012 Venericardia (Pacificor) iheringi (Böhm); Scasso et al., p. 43 , fig. $4 \mathrm{G}$.

Type specimen.-Holotype MACN-Pi 360, articulated shell from 'Río Chico' (Chubut Province, Salamanca Formation).

Diagnosis.-Outline subrectangular to subovate with rounded posterior margin. Lunule deep. Right anterior tooth inclined backwards, placed on anterior side of left anterior socket. Radial ribs (30-33) sculptured with closely spaced subcircular nodes and with narrow intercostal spaces.

Occurrence.-General Roca and Coli Toro Plateau areas (early Danian, Roca Formation, Río Negro Province), Opaso (early Danian, Jagüel Formation, Neuquén Province), and Río Chico's area (early Danian, Salamanca Formation, Chubut Province).

Description.-Shell thick, medium-sized, subrectangular to subovate in anterior-posterior direction, with elongate outline; posterior rounded, slightly curved ventral and gently inclined dorsal margins; posterior area defined by smooth convexity change starting from the eighth rib. Small umbones placed near anterior fifth of valve length. Lunule small, vertical, slightly concave, demarcated by an incised groove from remaining surface of shell, sculptured with fine commarginal growth lines.

Right valve hinge with sinuous ventral edge below middle tooth; small, short anterior tooth inclined backwards, thin, parallel to middle tooth, placed on anterior side of left anterior socket; middle tooth triangular, inclined strongly backwards, with narrow base, fine striations on dorsal surface, higher towards apex in lateral view; posterior tooth thin, slightly curved, taller than anterior one but shorter than middle tooth.

Left valve hinge with almost straight ventral edge; anterior tooth elongate, triangular, inclined backwards, slightly curved, with straight anterior and curved posterior sides; posterior tooth elongate, narrow, straight, with narrow base and acute apex, equal in height to anterior tooth. 

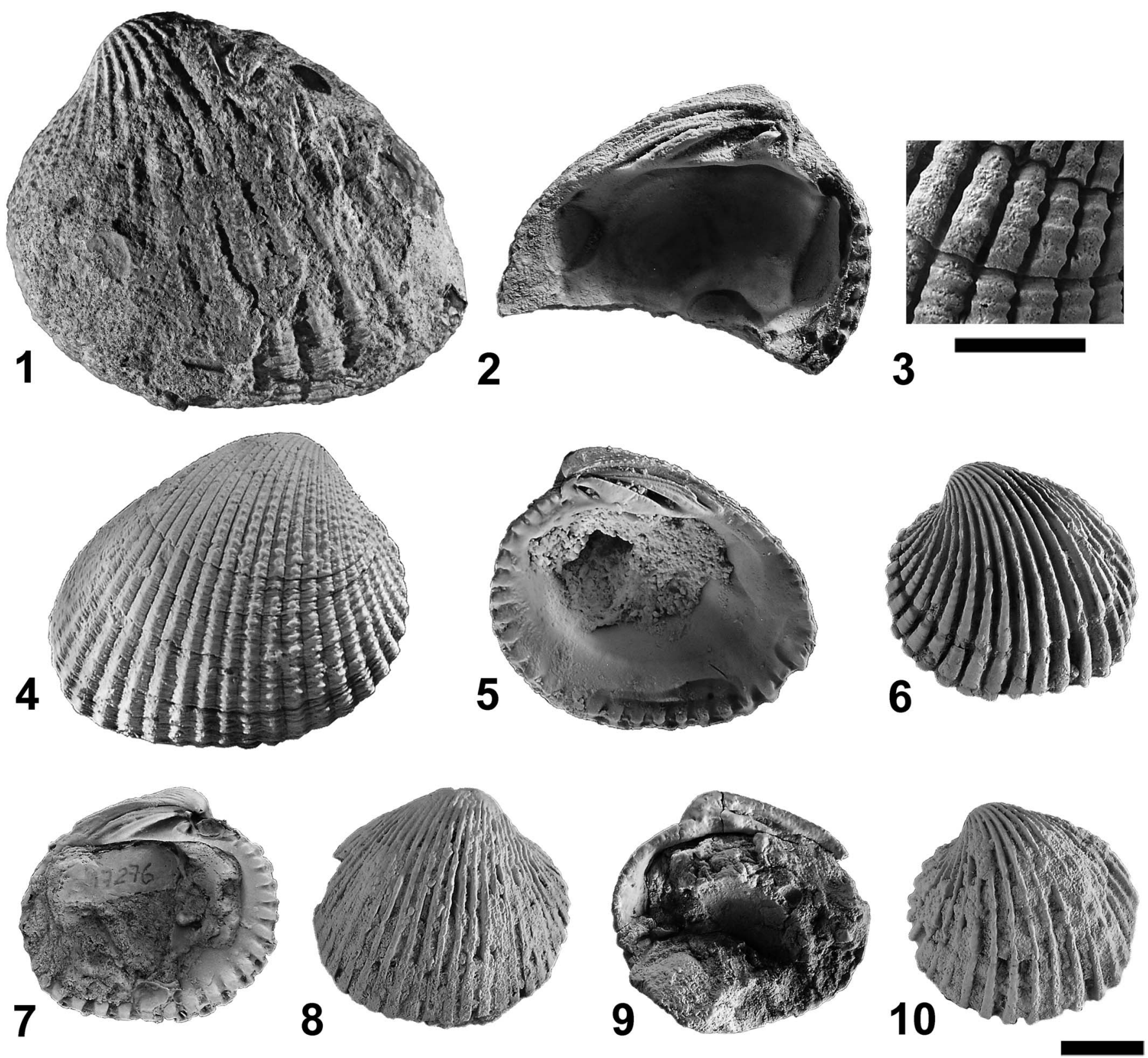

Figure 3. Claibornicardia paleopatagonica (Ihering, 1903) (1, 2, 4, 5): (1) external view of left valve, holotype MACN-Pi 360, from 'Río Chico'; (2) internal view of left valve, MACN-Pi 5197, from Puesto Ramírez; (4) external view of right valve, MACN-Pi 5197, from Puesto Ramírez; (5) internal view of right valve, MACN-Pi 5197, from Puesto Ramírez. Rotundicardia mariobrosorum n. sp. (3, 6-10): (3) detail of sculpture, MACN-Pi 5762, from Puesto Carmelo Ibañez: (6) external view of left valve, holotype CPBA 17276, from Cerro Tiltilco; (7) internal view of left valve, holotype CPBA 17276, from Cerro Tiltilco; (8) external view of right valve, Paratype MACN-Pi 5758, from Puesto Nancucheo; (9) internal view of right valve, Paratype MACN-Pi 5758, from Puesto Nancucheo; (10) external view of left valve, Paratype MACN-Pi 5758, from Puesto Ñancucheo. All scale bars represents $10 \mathrm{~mm}$.

External sculpture with 30-33 radial ribs having a subtriangular transverse section, widening in ventral direction; elevated central costal rib covered by nodes with subcircular transverse section; smooth paracostal ribs of rounded transverse section, as wide as central rib; narrow intercostal spaces delimited by deep, narrow groove; posterior area sculptured with eight weaker, less-high ribs, with less pronounced tripartition, first three ribs with stronger, more elevated nodes than the remainder.

Pallial line at a quarter of total valve height. Inner ventral margin strongly crenulated; crenulations triangular, truncated, covering entire margin to posterior adductor muscle scar, becoming smaller over posterior.

Materials.-CPBA 17286, 17288, 21027, 21028, MACN-Pi 4289, 5197, MLP 1475, 3731, 3732, and 3734 (26 left valves, 25 right valves, one articulated shell, one internal mold, and two external molds).

Remarks.-Ihering (1903) described C. paleopatagonica based on a shell with conjoined valves from 'Río Chico' (Salamanca Formation), stating that the type specimen did not allow the 
description of hinge features. Ihering (1907) mentioned other specimens of $C$. paleopatagonica from 'Rocanense' exposures from an unspecified locality, but only the type specimen is present in Ihering's collection.

Feruglio (1936, pl. 23, figs. 28, 29) described and illustrated specimens from Puesto Ramírez (Danian, Salamanca Formation, Chubut Province) and later, Vigilante (1977, pl. 1, fig. 6) assigned one of the juvenile specimens collected by Feruglio to V. camachoi Vigilante, 1977. Both authors referred their species to Venericardia Lamarck, 1801 (type species $V$. imbricata Lamarck, 1801, Eocene, Paris Basin) (see La Perna et al., 2017, fig. 3). However, C. paleopatagonica is placed in Claibornicardia because of its subrectangular outline, sinuous ventral hinge margin, thin right anterior teeth, and the presence of wide paracostal ribs with narrow intercostals spaces.

Rodríguez et al. (1995, pl. 2, figs. G, H) illustrated C. paleopatagonica from Cerro Tiltilco (Roca Formation, Río Negro Province), and included it in Glyptoactis Stewart, 1930, (type species V. hadra Dall, 1903, Miocene, Florida, USA) (Heaslip, 1968, pl. 27-29), but this genus has a triangular outline, larger and more recurved umbones, a deeper lunule with the ventrally projecting lunular margin, right hinge ventral edge inverted ' $\mathrm{V}$ '-shaped, right middle and left posterior teeth more curved, fewer radial ribs with wider paracostal ribs, and narrower intercostal spaces.

Claibornicardia paleopatagonica differs from C. alticostata (Stenzel et al., 1957, pl. 13, figs. 1-9; Heaslip, 1968, pl. 26, figs. 6-11) by its rounded posterior margin, deeper lunule, weaker left anterior tooth, a right anterior tooth that is inclined backwards and placed on the anterior side of the left anterior socket, and by its stronger radial nodes. Juvenile specimens of $C$. paleopatagonica have subquadrate outlines, while adults are more elongate. The same variation can be observed in C. alticostata (syntypes ANSP 30562 include elongate adults and subquadrate juveniles) (Stenzel et al., 1957).

Species from the middle Eocene of the USA are mainly distinguished from each other and from C. paleopatagonica by their outlines. Claibornicardia linguinodifera Heaslip, 1968 (Stenzel et al., 1957, pl. 14, figs. 6-11; Heaslip, 1968, pl. 24, figs. 1, 2; Bashi and Reklaw formations), C. coloradonis (Harris, 1919) (Heaslip, 1968, pl. 24, figs. 3-6; Weches, Wautubbee, and Reklaw formations), and C. natchitoches (Harris, 1919) (Heaslip, 1968, pl. 25, figs. 4-7; Weches Formation) have less elongated outlines, with truncated posterior margins, wide intercostal spaces, and more closely spaced nodes than C. paleopatagonica. Claibornicardia perantiqua (Conrad, 1865) (Heaslip, 1968, pl. 25, figs. 8-11; Shark River Formation), C. trapaquara (Harris, 1895) (Stenzel et al., 1957, pl. 14, figs. 6-11; Heaslip, 1968, pl. 24, fig. 8, pl. 25, figs. 1-3; Stone City Beds), and C. trapaquaroides Heaslip, 1968 (Heaslip, 1968, pl. 24, fig. 7; Weches Formation) can be distinguished from the Patagonian species because their shells have a more acuminated postero-ventral margin, less rounded nodes, and wider intercostal spaces.

Claibornicardia paleopatagonica differs from C. complexicostata (Meyer and Aldrich, 1886) (Stenzel et al., 1957, pl. 15, figs. 1-4; Heaslip, 1968, pl. 26, figs. 3-5; Wautubbe Formation) by having a subrectangular to subovate shell instead of the subtriangular outlines of the American species.
Claibornicardia blandingi (Conrad, 1830) (Heaslip, 1968, pl. 26, figs. 1, 2; Lower Santee Limestone Formation) and C. paleopatagonica have similar shell-shapes, but can be distinguished by the larger shells sculptured with a greater number of radial ribs in the Patagonian species.

Claibornicardia paleopatagonica can be distinguished from C. keenae (Verastegui, 1953) (Moore, 1992, pl. 8, figs. 6, 8, 10, 12, 13, 15; Lodo Formation, late Paleocene-early Eocene, California, USA, and Getkilninskaya Formation, late Paleocene, Russia) by having a deeper lunule, and more numerous radial ribs.

\section{Genus Rotundicardia Heaslip, 1968}

Type species.-Venericardia rotunda Lea, 1833 (by original designation). Gosport Sand, Lisbon, Wautubbee, McBean, Cook Mountain, Weches and Yegua formations, middle Eocene of the USA and Laredo Formation, middle Eocene of México.

Diagnosis.-Carditid with a moderately convex shell, subrounded outline, and slightly truncated posterior margin. Umbones small, placed subcentrally. Lunule reduced or absent. Right middle tooth prominent, broad; left anterior tooth strong, triangular. Radial ribs (25-26) high, covered with funginate nodes, and paracostal ribs reduced or absent in many species (modified from Heaslip, 1968, p. 90).

Remarks.-According to Heaslip (1968), the main features of Rotundicardia are the subrounded shell shape with centrally placed umbones, and the funginated nodes. Heaslip (1968) included seven species from the GCP in Rotundicardia: R. carsonensis (Dall, 1903), R. crenaea (Gardner, 1935), R. diversidentata (Meyer, 1885), R. eoa (Gardner, 1935), R. eutawcolensis (Harris, 1919), R. flabellum (Harris, 1919), and $R$. rotunda (Lea, 1833). He also recognized the presence of sexual dimorphism within $R$. rotunda and $R$. diversidentata, identified by the development in males of less convex shells than in females, which are more strongly sculptured.

Beal (1948) recorded Venericardia cf. V. rotunda (Tepetate Formation, middle Eocene, Baja California, Mexico) and Woodring (1982) recorded Rotundicardia sp. for the late Eocene of Panamá. Darragh (1994) included two species from Australia within Rotundicardia: $R$. petraea (Darragh, 1994) from the middle Paleocene, and $R$. latissima (Tate, 1886) from the middle Eocene. The latter was placed within Fasciculardia by Maxwell (1969).

The oldest known record for the genus is the late Danian $R$. crenaea (Gardner, 1935) from the Kincaid Formation (Tehuacana Member, Texas, USA), assigned to this age by Barnes et al. (1992).

\section{Rotundicardia mariobrosorum new species}

Figure 3.3, 3.6-3.10

1995 Glyptoactis feruglioi (Petersen): Rodríguez et al., p. 243, pl. 2, fig. 1 .

Type specimens.-Holotype CPBA 17276, one left valve from Cerro Tiltilco (Río Negro Province). Paratype MACN-Pi 5758, right and left valve from Puesto Ñancucheo (Río Negro Province). 
Diagnosis.-Shells with a subquadrate outline. Lunule absent. Right anterior tooth minute; left anterior tooth small, short, and inclined backwards. Radial ribs (25-27) increasing in width towards ventral margin, without paracostal ribs, and with strongly funginated nodes.

Occurrence.-General Roca and Coli Toro Plateau areas (Danian, Roca Formation, Río Negro Province).

Description.-Shell medium-sized to small, subquadrate to subrounded, with rounded anterior and ventral margins, convex dorsal margin, and almost straight posterior margin. Umbones placed near middle of valve length. Lunule absent. Right valve hinge with straight or slightly curved ventral edge; right anterior tooth reduced, thin, straight, in contact with middle tooth; middle tooth triangular, inclined backwards, with wide base, higher than other teeth; posterior tooth straight, thin. Left valve hinge with nearly straight ventral edge; anterior tooth small, short, inclined backwards, with short anterior and convex posterior edges; posterior tooth narrow, slightly curved, higher than anterior tooth, with sharp dorsal tip, ventral surface finely striate. External sculpture of 25-27 radial ribs of triangular transverse section, without paracostal ribs, wider towards ventral margin; high central costal cord with subrectangular funginated nodes, more numerous towards ventral and anterior margins; intercostal spaces of ' $\mathrm{V}$ '-shaped transversal section, each narrower than one radial rib. Pallial line at one-quarter of total valve height. Inner ventral margin strongly crenulate, crenulations triangular, with sharp tips, covering entire margin to dorsal edge of adductor posterior muscle scar.

Etymology.-The specific epithet honors Mario and Luigi, the Mario Bros. brothers, main characters from the popular videogame Mario Bros., in which they collect mushrooms, and it is a reference to the 'funginate' nodes of the radial ribs in this species.

Materials.-MACN-Pi 4180, 5758-5762, 5766 (17 left valves, 13 right valves, and one fragment).

Remarks.-The specimen assigned to Glyptoactis feruglioi Petersen, 1946 by Rodríguez et al. (1995, pl. 2, fig. 1) from Cerro Tiltilco is placed in $R$. mariobrosorum n. sp. The new species differs from $G$. feruglioi by its less triangular outline with a truncated posterior margin, its smaller hinge, the presence of a right anterior tooth, and its smaller right middle tooth.

The new species is placed in Rotundicardia because it has a subquadrate outline with slightly truncated posterior margin, 25-27 radial ribs covered with funginated nodes, and because it lacks a lunule and paracostal ribs. Glyptoactis Stewart, 1930 (type species V. hadra Dall, 1903, Miocene, Florida, USA) (Heaslip, 1968, pls. 27-29), the genus where Rodríguez et al. (1995) placed these shells, has a more triangular outline, with larger and more prominent umbones, fewer radial ribs (19-20) covered with small subrectangular nodes.

Rotundicardia mariobrosorum n. sp. differs from R. rotunda (Lea, 1833) (Heaslip, 1968, pl. 22, figs. 8, 9, pl. 23, figs. 1,2 ) by its subquadrate shells, smaller right anterior tooth, shorter and smaller left anterior tooth, and radial ribs becoming wider towards the ventral margin. Rotundicardia diversidentata (Meyer, 1885) (Heaslip, 1968, pl. 23, figs. 3-8, Jackson and Ocala Limestone formations, late Eocene, USA) differs from $R$. mariobrosorum $\mathrm{n}$. sp. in having the same characters as $R$. rotunda, and a lunule and less pronounced nodes.

Rotundicardia mariobrosorum can be distinguished from R. eoa (Gardner, 1935) (Heaslip 1968, pl. 22, figs. 1, 2) and R. crenaea (Gardner, 1935) (Heaslip, 1968, pl. 22, figs. 3, 4) (Kincaid Formation, late Danian, USA) because both the latter species have fewer radial ribs $(\sim 23)$ covered with less pronounced nodes, and have paracostal ribs, that are absent from $R$. mariobrosorum $\mathrm{n}$. sp.

Rotundicardia flabellum (Harris, 1919) (Heaslip, 1968, pl. 22, figs. 6, 7, Weches and Yegua formations, middle Eocene, USA) and $R$. carsonensis (Dall, 1903) (Heaslip, 1968, pl. 23, figs. 9, 10, Red Bluff Formation, early Oligocene, USA and from an unnamed formation, early Oligocene, Mexico) are distinguished from $R$. mariobrosorum by the presence of a lunule, by having a larger anterior right tooth, and by having radial ribs of equal width throughout the ontogeny.

Rotundicardia mariobrosorum differs from $R$. petraea Darragh, 1994 (Darragh, 1994, fig. 6E, 6F, 6I-6L, Pebble Point and Kings Park formations, late Paleocene, Australia) by having a slightly truncated posterior margin instead of the expanded posterior margin that characterizes the Australian species.

Rotundicardia latissima (Tate, 1886) (Darragh and Kendrick, 2008, fig. 1.5, Lower Browns Creek, Upper Browns Creek, Blanche Point formations and Southern Carnavon Basin, middle-late Eocene, Australia) can be distinguished from $R$. mariobrosorum because the South American species has a more subquadrate shape and radial ribs with more prominent nodes.

Genus Cardites Link, 1807

Type species.-Chama antiquata Linnaeus, 1758 (by original designation). Miocene-Recent of Europe and Northern Africa.

Diagnosis.-Carditid with very convex shell, subtriangular to subrounded in shape with a truncated posterior margin. Umbones prominent. Lunule convex. Right anterior tooth extremely faint; absent in some species. Radial ribs wide, sculptured with beaded or rectangular nodes.

Remarks. - The key character of Cardites is the presence of a very faint right anterior tooth (Link, 1807; Chavan, 1969), absent according to other authors (Dall, 1902; Lamy, 1921). This tooth could be present with varying degrees of development within different species of the genus (see for examples Lamy, 1921, p. 202; Chavan, 1969, fig. E56.1; Huber, 2010, p. 251). The diagnoses provided by Dall (1902), Lamy (1921), and Chavan (1969) are incomplete for a definition of Cardites. Because of this, we give an emended diagnosis herein.

The oldest records for Cardites are C. dertopartschii (Sacco, 1899) and C. partschii (Goldfuss, 1840) from the Burdigalian (early Miocene) of the Vienna Basin (Sieber, 1954). Cardites has a wide stratigraphical and geographical range, and has been cited from Miocene of Europe (Jimenez and Braga, 1993; Lacour et al., 2002) and North Africa (Freneix et al., 1987), from the Pliocene of 
Panamá (Collins and Coates, 1999) and Ecuador (Olsson, 1941), and from the Pleistocene of East Asia (Cox, 1931), North Africa (El-Sorogy, 2002), Australia (McNamara and Kendrick, 1994), Europe (Menesini and Ughi, 1982), and Ecuador (Olsson, 1964). Most of these records have never been reviewed, and a few of these records may not be Cardites. For example, La Perna et al. (2017) recently placed the species $C$. ignoratus (Cossman and Peyrot, 1912) in Megacardita Sacco, 1899.

The only reference to Cardites from the USA was provided by Whitfield (1885), who mentioned C. antiquatus as occurring in the Shark River Formation (Eocene of New Jersey). However, Palmer and Brann (1965) pointed out that this record mistakenly confused the name with Claibornicardia perantiqua (Conrad, 1865).

Huber (2010) suggested that living species referred to Cardites include species belonging to at least two different genera. He recognizing a group of elongated species from America, including C. floridanus (Conrad, 1838), C. grayi (Dall, 1903), and C. laticostatus (Sowerby, 1833), and another group composed of species with triangular and subrounded shells from Europe and Asia, including C. antiquatus (Linnaeus, 1758), C. bicolor (Lamarck, 1819), C. canaliculatus (Reeve, 1843), and C. ovalis (Reeve, 1843). The American species have a notch at the posterior margin and radial ribs with squamose nodes, while the European and Asian species have radial ribs with subrectangular nodes. Therefore, Huber's (2010) hypothesis that American taxa could belong to distinct genera from European and Asian taxa could potentially be corroborated based upon morphological differences and distinct geographical distributions.

\section{Cardites feruglioi (Petersen, 1946)}

Figure 4.1-4.6

1946 Venericardia feruglioi Petersen, p. 126, pl. 10, figs. 3-5. 1990 Venericardia feruglioi Petersen; Medina et al., p. 140, pl. 1, figs. 1-3.

1992 Venericardia feruglioi Petersen; Camacho, p. 37.

Type specimens.-Syntypes SGN 9379 and SGN 9381. One right and one left valve, from Puesto Crettón, (Chubut Province).

Diagnosis. - Shell subtriangular to subrectangular outline, with sinuous ventral margin. Lunule small. Left anterior tooth small and triangular; right middle tooth very curved, broad, and prominent. Radial ribs (28-29) with elongated rectangular nodes, better developed on ventral and posterior regions of valves than elsewhere, and with reduced intercostal spaces.

Occurrence.-General Roca and Coli Toro Plateau areas (Danian, Roca Formation, Río Negro Province), and Puesto Crettón (Danian, Lefipán Formation, Chubut Province).

Description.-Shell medium-sized, thick, triangular to subrectangular; anterior margin rounded, ventral margin sinuous, posterior margin truncated with right angle between it and ventral one, dorsal margin inclined, slightly convex; posterior area defined by convexity change starting from seventh or eighth radial rib. Umbones large, recurved, placed near anterior third of valve length. Lunule very small. Hinge of right valve high, with sinuous ventral edge below middle tooth; anterior tooth absent; middle tooth large, high, strongly curved, inclined backwards, with broad base, dorsal tip sharp; fine striations on dorsal surface; posterior tooth long, thin, curved.

Hinge of left valve high, with straight ventral edge; anterior tooth short, triangular, inclined backwards, with straight anterior and curved posterior edges; posterior tooth long, curved, higher than anterior one. External sculpture of 28-29 broad, low radial ribs of subrectangular transverse section, covered with obsolete and elongated rectangular nodes, more strongly developed on ventral and posterior regions of valve; intercostal spaces reduced, with ' $\mathrm{V}$ '-shaped transverse section; posterior area covered with seven or eight lower, narrower radial ribs. Pallial line at about one-quarter of valve height. Inner ventral margin with strong crenulations that are rectangular, truncated, and extend around margin until junction of ventral and posterior margins.

Materials.-SGN 9395; MACN-Pi 4120, 4197, 5748, 57635765, 5767; CPBA 6411 (39 left valves, 27 right valves, one articulated shell, one internal mold, and eight fragments).

Remarks.-Petersen (1946) erected C. feruglioi based on a large number of shells collected from the Danian section of the Lefipán Formation, exposed in the middle Chubut River area (Chubut Province). Later, Rodríguez et al. (1995) assigned a left valve (CPBA 17276) to this species from Cerro Tiltilco (Roca Formation, Río Negro Province). This specimen does not resemble the specimens in Petersen (1946), therefore we included it in the new species. The description of $C$. feruglioi is expanded here to include new specimens from Puesto Nahuel Cheo, Puesto Carmelo Ibañez, and unspecified fossiliferous sections describe by R. Wichmann at Bajo Lenza Niyeu and Bajos Hondos. Petersen (1946) assigned this species to Venericardia, but that genus has subquadrate shells, strongly truncated posterior margin, and paracostal ribs sculptured with rounded nodes. The presence in $C$. feruglioi of subtriangular shells, radial ribs covered with subrectangular nodes, without paracostal ribs, and the absence of a right anterior tooth place this species within Cardites Link, 1807.

Cardites feruglioi differs from $C$. antiquatus (Linnaeus, 1758) (Chavan, 1969, fig. E56.1) by its larger shells with subtriangular outlines, a sinuous ventral margin, shorter left anterior and wider right middle teeth, and a greater number of radial ribs that are more strongly developed on the ventral and posterior regions of the valves.

Cardites canaliculatus (Reeve, 1843), C. bicolor (Lamarck, 1819) (Recent, Indian Ocean), and other subtriangular species from Europe and Asia (Huber, 2010, p. 251-252) can all be distinguished from $C$. feruglioi by having a larger lunule and sculpture with fewer radial ribs.

Cardites floridanus (Conrad, 1838) (Recent, from North Carolina, USA to Northern Brazil) and the remaining elongate American species (Huber, 2010, p. 251-252) differ from C. feruglioi by their elongate outlines, with more rounded umbones and large lunules. 

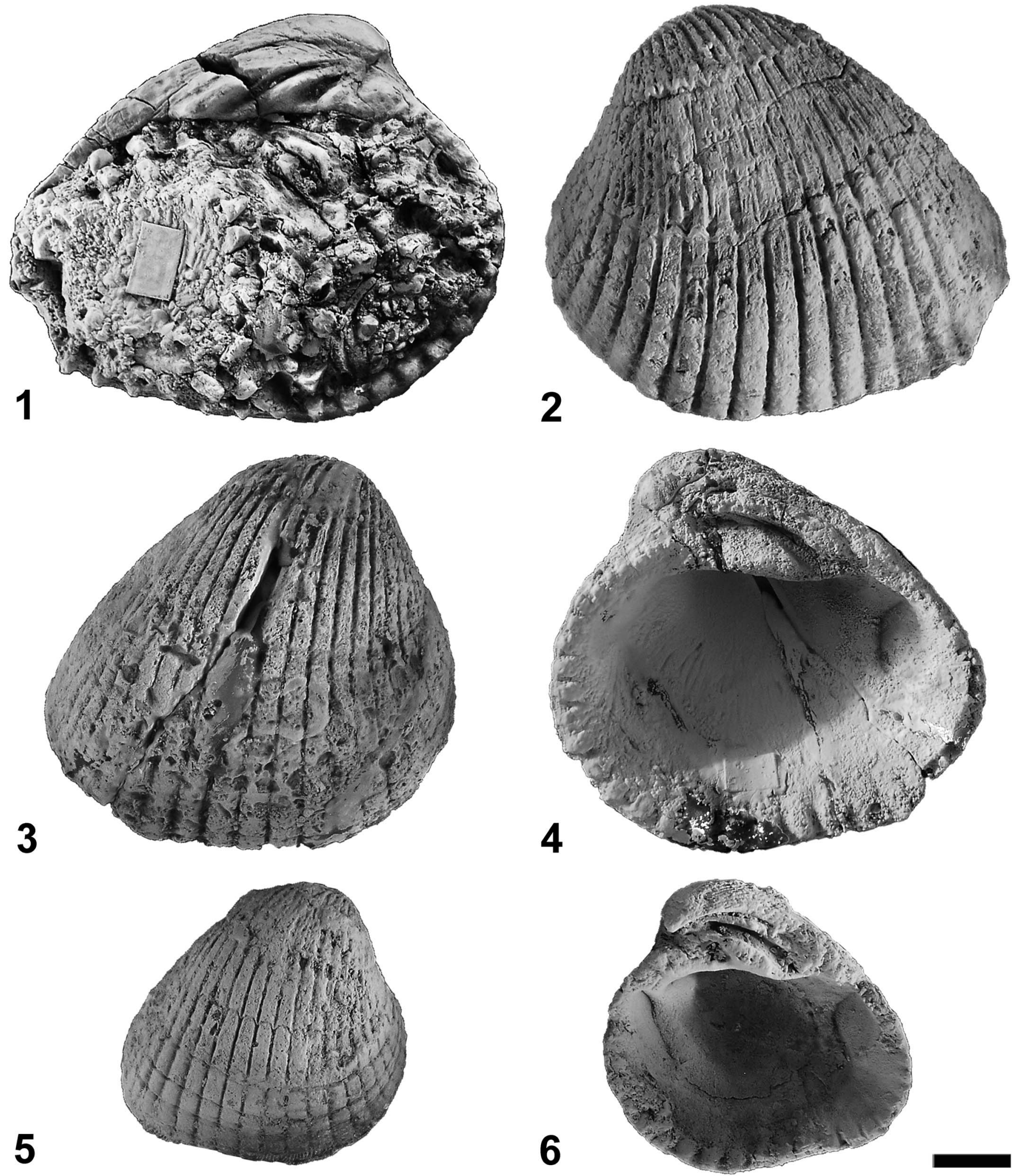

Figure 4. Cardites feruglioi (Petersen, 1946): (1) internal view of left valve, syntype SGN 9381, from Puesto Crettón; (2) external view of left valve, syntype SGN 9381, from Puesto Crettón; (3) external view of right valve, syntype SGN 9379, from Puesto Crettón; (4) internal view of right valve, syntype SGN 9379, from Puesto Crettón; (5) external view of right valve, MACN-Pi 5763, from Cerro Tiltilco; (6) internal view of right valve, MACN-Pi 5763, from Cerro Tiltilco. Scale bar represents $10 \mathrm{~mm}$. 
Cardites feruglioi can be distinguished from C. partschii (Goldfuss, 1840) (Miocene from Europe; Sieber, 1954, pl. 1, fig. 3) by having a larger shell with subtriangular outlines, and narrower radial ribs that become better developed on the ventral and posterior regions of the valves and are separated by wider intercostal spaces.

\section{Genus Kalelia new genus}

Type species.-Cardita multicostata Lamarck, 1806. Late Paleocene, Paris Basin, France.

Included species.—K. burmeisteri (Böhm, 1903), K. pectuncularis (Lamarck, 1806).

Diagnosis. - Carditid with large shells for the family, thick and subcircular. Posterior margin convex, large umbones and posterior area defined by an umbonal carina and a convexity change. Lunule large, vertically oriented. Hinge high, with wide ventral development. Right anterior tooth long, inclined backwards; right middle tooth thick, strongly curved, with broad base. Left anterior tooth triangular, very broad, inclined backwards, with very convex posterior edge. External sculpture of tripartited radial ribs, 25-30 wide, most prominent on anterior, intercostals spaces confined to a narrow groove.

Etymology.-The name honors Kal-El, Kryptonian name of Superman, the first superhero in comic books. This genus is one of the oldest and largest alticostate carditids.

Remarks.-Kalelia $\mathrm{n}$. gen. is the largest member of all alticostate carditids, with shells reaching up to $60 \mathrm{~mm}$ in height. It is characterized by the development of a tall hinge plate, prominent teeth, a large lunule, and the presence of low radial ribs; subrectangular in cross section. These characters are shared with planicostate carditids, but the development of tripartite radial ribs places Kalelia within alticostates carditids. Rutsch (1936) and McClure (2009) already mentioned the possibility that 'Venericardia' pectuncularis convergently developed some planicostate characters.

We proposed including in Kalelia n. gen., apart from the type species 'Cardita' multicostata (Lamarck, 1806) (Cossmann and Pissarro, 1904, pl. 31, fig. 97-3), the late Paleocene species 'C.' burmeisteri (Böhm, 1903) (Roca and Salamanca formations, early Danian, Argentina) (Fig. 5.1-5.11) and 'C.' pectuncularis (Lamarck, 1806) (Cossmann and Pissarro, 1904, pl. 31, fig. 97-2) (Fig. 6.1, 6.2), from the Sables de Bracheux, France. These species have large shells with strong hinge teeth and the particular external sculpture described above. The poorly known species ' $V$.' marylandica (Clark and Martin, 1901) (Clark and Martin, 1901, pl. 40, fig. 7; Nanjemoy
Formation, early Eocene, USA) is possibly a North American representative of this genus.

Kalelia n. gen. differs from Venericardia Lamarck, 1801 (La Perna et al., 2017, fig. 3) in having larger shells with more nearly circular outlines, a convex posterior margin instead of a truncated one, a larger lunule, a higher hinge plate, a triangular right anterior tooth, and fewer radial ribs that are separated by intercostal spaces defined by narrow grooves.

Kalelia n. gen. can be distinguished from Arcturellina Chavan, 1951 (type species C. asperula Deshayes, 1825, Eocene, Paris Basin) (Cossmann and Pissarro, 1904, pl. 22, fig. 97-22) by having larger shells, convex posterior margin, higher hinge plate, long or straight right anterior tooth, triangular left anterior tooth, and fewer radial ribs covered with subcircular nodes instead of the subrectangular ones that characterize Arcturellina.

Kalelia n. gen. can be distinguished from Claibornicardia Stenzel and Krause, 1957 (Heaslip, 1968, pl. 26, figs. 6-11) because Kalelia has larger and more nearly circular shells, a higher and more robust hinge, and fewer, lower, and wide radial ribs.

Kalelia n. gen. can be separated from Rotundicardia Heaslip, 1968 (Heaslip, 1968, pl. 22, figs. 8-9, pl. 23, figs. 1-2) by having a rounded posterior margin, convex umbones, a welldeveloped posterior area, the presence of a lunule, the higher number of radial ribs with subcircular nodes, and narrower intercostals spaces separating the ribs.

\section{Kalelia burmeisteri (Böhm, 1903) n. comb. Figure 5.1-5.7}

1902 Cardita morganiana Rathbun; Burckhardt, p. 216, figs. 1,7 .

1903 Cardita burmeisteri Böhm, p. 72.

1903 Cardita Burckhardti Ihering, p. 205.

1907 Venericardia burmeisteri (Böhm); Ihering, p. 23.

1938b Venericardia burmeisteri (Böhm), 'Forma B'; FossaMancini, p. 263.

1967 Venericardia paleopatagonica var. australis Masiuk, p. 243 , pl. 5, fig. 2 .

Type specimens.-Holotype MLP 15294a and 15294f. Two internal molds from General Roca (Río Negro Province).

Diagnosis.-Shell medium-sized, posterior margin slightly convex, dorsal margin sloping from beaks to posterior one, posterior area sculptured by three or four higher and wide radial ribs, continued by three lower and narrower other ones. Umbones subcentrally placed. External sculpture of 25 wide and low radial ribs.

Occurrence.-General Roca area (early Danian, Roca Formation, Río Negro Province) and Puesto Álvarez (early Danian, Salamanca Formation, Chubut Province).

Figure 5. Kalelia burmeisteri (Böhm, 1903) n. comb. (1-7): (1) external view of left valve, CPBA 8338, from Puesto Álvarez; (2) external view of left valve with shell removed, CPBA 8338, from Puesto Álvarez; (3) external view of right valve, CPBA 8338, from Puesto Álvarez; (4) internal view of right valve, MACN-Pi 5357, from General Roca; (5) left view of internal mold, CPBA 8338, from Puesto Álvarez; (6) left view of internal mold, holotype MLP 15294f, from General Roca; (7) left view of internal mold, holotype MLP 15294a, from General Roca. Kalelia multicostata (Lamarck, 1806) n. comb. (8-11): (8) internal view of left valve, holotype MNHN A07711, from Abbecourt, France; (9) external view of left valve, holotype MNHN A07711, from Abbecourt, France; (10) internal view of right valve, MNHN F07559, from Noailles, France; (11) external view of right valve, MNHN F07559, from Noailles, France. Scale bar represents $10 \mathrm{~mm}$. 

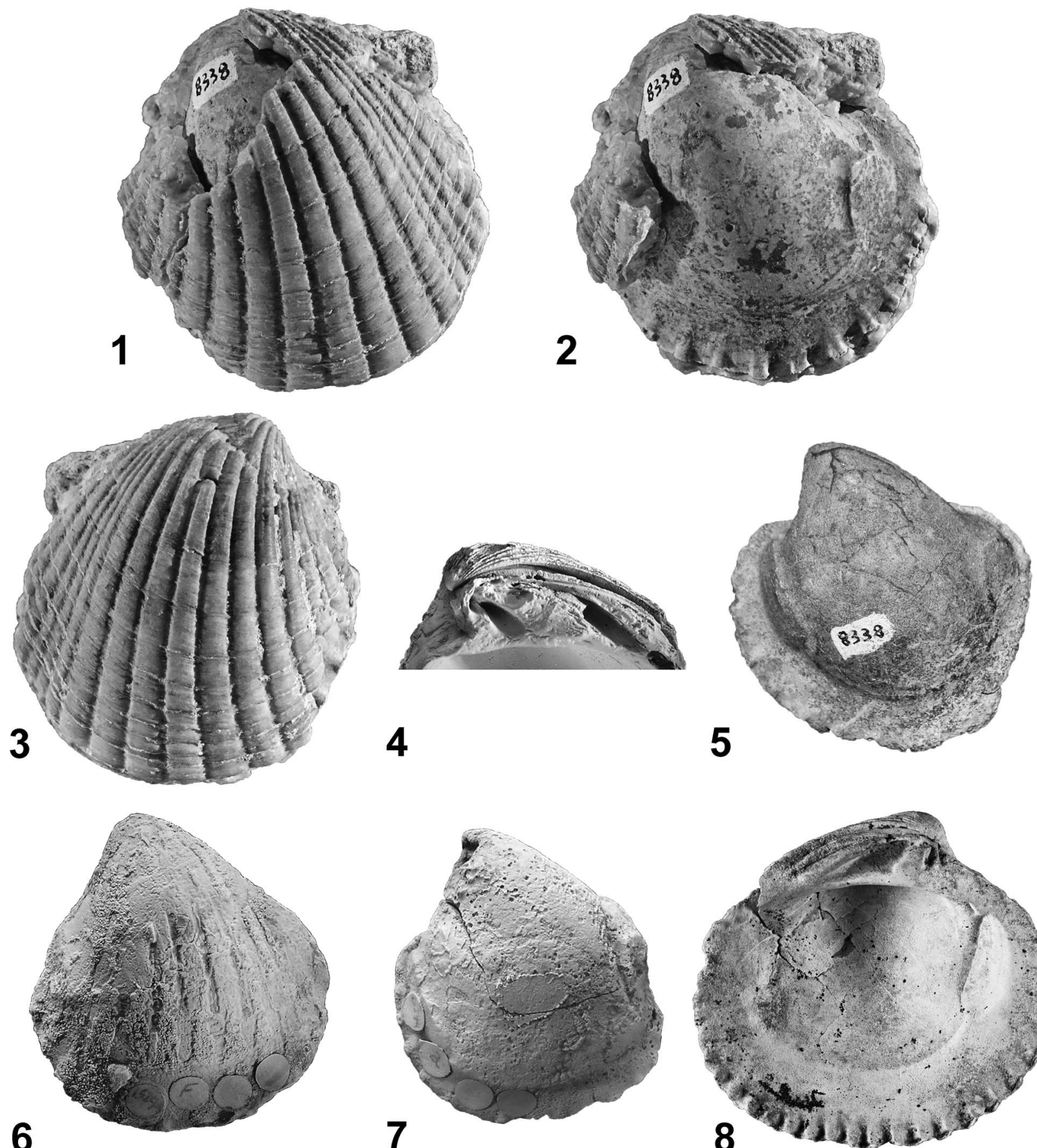

4
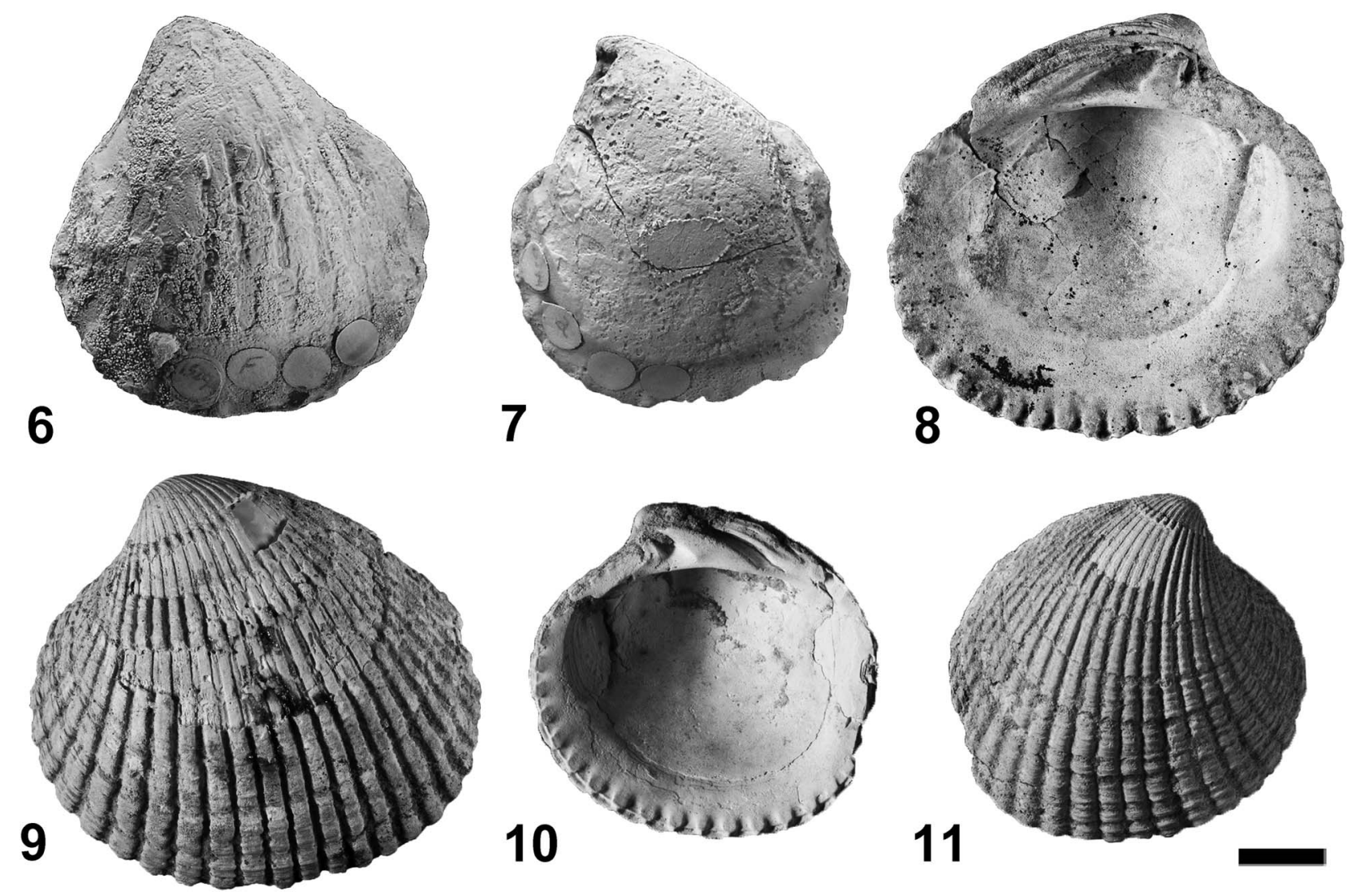


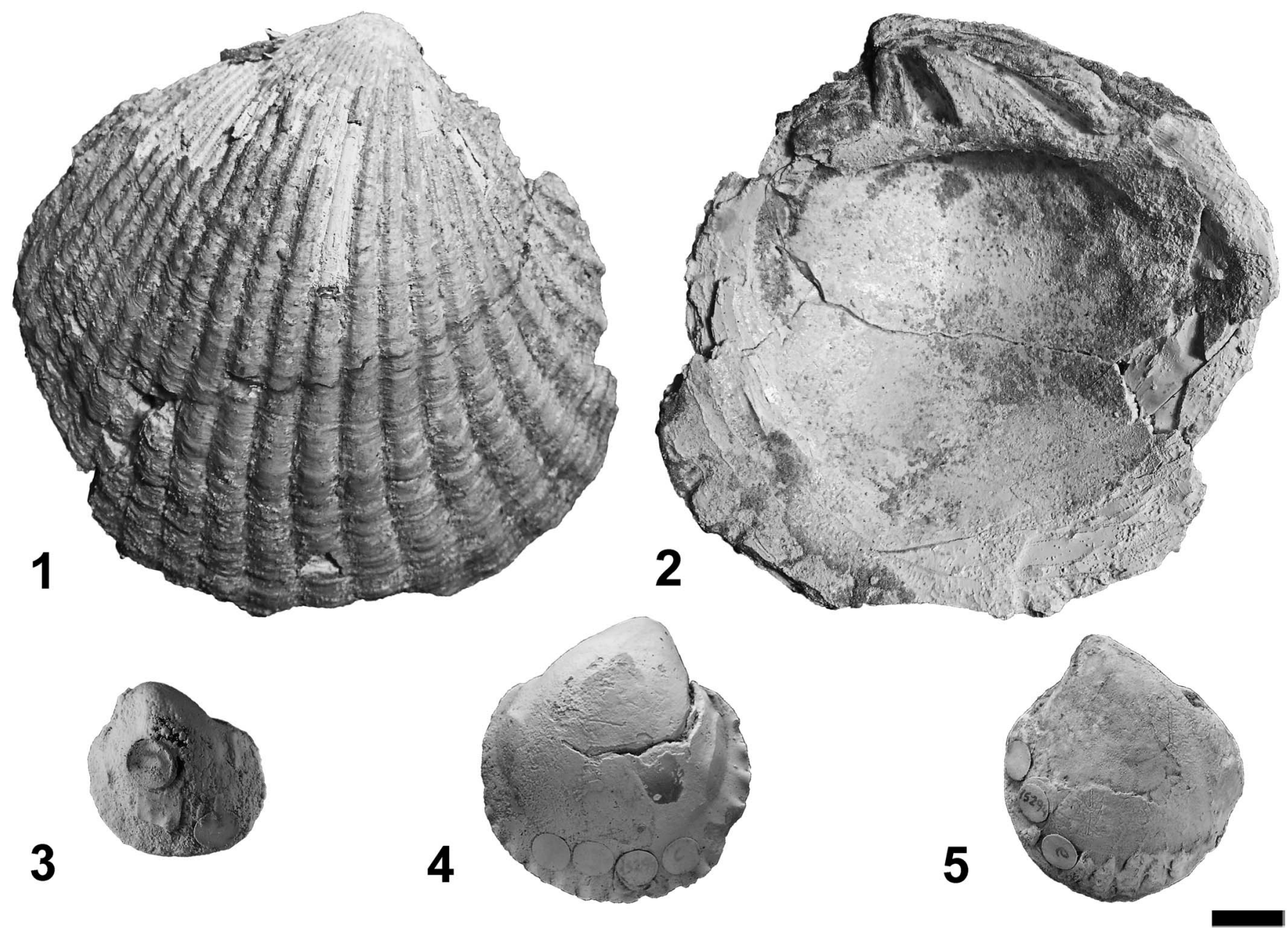

Figure 6. Kalelia pectuncularis (Lamarck, 1806) n. comb. (1, 2): (1) external view of right valve, holotype GMNH 46030, from Bracheaux, France; (2) internal view of right valve, holotype GMNH 46030, from Bracheaux, France. 'Venericardia' iheringi (Böhm, 1903) (3-5): (3) left view of internal mold, MLP 10220a, from Puesto Pircala; (4) right view of internal mold, syntype MLP 15294c, from General Roca; (5) left view of internal mold, syntype MLP $15294 \mathrm{c}$, from General Roca. Scale bar represents $10 \mathrm{~mm}$.

Description.-Shell medium-sized, thick, subcircular in outline, with rounded anterior and ventral margins, weakly convex posterior margin, and curved dorsal margin with pronounced slope from beaks to posterior end; posterior area defined by convexity change starting from sixth or seventh radial rib. Umbones large, convex, near center of valves. Lunule large, convex, sunken, vertically oriented. Right valve hinge with straight ventral edge; anterior tooth thin, large, inclined backwards; middle tooth large, strongly curved, strongly inclined backwards, with broad base, higher towards dorsal extreme in lateral view; posterior tooth thin, curved, extending to center of middle tooth. Left hinge not seen. External sculpture of 25 wide, low, tripartite radial ribs, more prominent towards anterior region of valves, transverse section triangular in dorsal region but semicircular in central region; central radial ribs covered with nodes, subcircular transverse in cross section; paracostal ribs smooth, semicircular transverse in cross section, as wide as central radial rib; intercostal spaces, subquadrate transverse in cross section, each wider than one radial rib; posterior area sculptured with three or four higher, wider ribs, followed by three lower and narrower ones. Pallial line at about one-quarter of total valve height. Inner ventral margin with prominent crenulation; crenulations triangular, truncated, extending along entire margin to center of posterior adductor muscle scar.

Materials.-CPBA 6402-6403, 6407, 8338; MACN-Pi 341343, 5747, 5751-5753, 5357; MLP 1876, 1878, 1882, 1897, 4098, 4475, 5517, 7286, 9108, 9416, 9724, 9725, 9768, 10504, 10505 (one left valve, two right valves, one articulated shells, and 81 internal molds).

Remarks.-Internal molds studied by Burckhardt (1902), Böhm (1903), and Ihering $(1903,1907)$ are characterized by their large size, subrounded outline, convex umbones, and particularly by the presence of a postero-ventral carina. The specimens collected by Masiuk (1967) and described as Venericardia paleopatagonica var. australis, include composite molds, with internal molds and valves that allowed us to identified Masiuk's variety with $K$. burmeisteri. The carina present in the molds corresponds to the change in convexity and sculpture observed in the preserved valves. 
Burckhardt (1902) identified this species as Cardita morganiana Rathbun, 1875, a Brazilian taxon from Maria Farinha (Paleocene) and Pirabas (Miocene) formations (Penna, 1965; Tavora et al., 2010). The Brazilian species (White, 1887, pl. 8, figs. 18-21) differs from K. burmeisteri in having smaller and more robust shells with umbones placed more anteriorly, and in having more pronounced tripartition and the ribs sculptured with squamose nodes.

Kalelia multicostata (Lamarck, 1806) (Cossmann and Pissarro, 1904, pl. 31, fig. 97-3; Sables de Bracheux) can be separated from $K$. burmeisteri by being larger, with a more horizontal dorsal margin, anteriorly placed umbones, the posterior area sculptured with radial ribs of equal width, and by having more numerous radial ribs with better-developed tripartition over center of the valves.

Kalelia burmeisteri is distinguished from $K$. pectuncularis (Lamarck, 1806) (Chenu, 1842, pl. 2, fig. 8; Cossmann and Pissarro, 1904, pl. 31, fig. 97-2; Sables de Bracheux) by its smaller size, sloping dorsal margin, subcentrally placed umbones, and fewer and wider radial ribs.

\section{Other Danian records of Carditidae}

Some records of Danian carditids from Argentina have an uncertain taxonomic status and affinities and they are reviewed below.

'Cardita' morganiana and 'Cardita' beaumonti._(Fig. 6.3; MLP 10220a-d). These two species have been mentioned frequently in the literature of the Paleocene from Argentina (Behrendsen, 1891; Burckhardt, 1900, 1902; Windhausen, 1918, 1931; Weaver, 1927, 1931; Gerth, 1935; Fossa Mancini, 1938a, 1938b).

As stated above, 'Cardita' morganiana Rathbun, 1875 is a Cenozoic Brazilian species that is possibly related to Baluchicardia Rutsch and Schenck, 1943. 'Cardita' morganiana was cited for the first time in Argentina from Puesto Pircala (Malargüe, Roca Formation, Mendoza Province) (Behrendsen, 1891), based on internal molds. These outcrops were assigned a Maastrichtian age by Parras et al. (1998). Burckhardt (1902) indicated the presence of ' $C$.' morganiana in the type area of the Roca Formation, which is of early Danian age according to del Río et al. (2011).

Weaver $(1927,1931)$ mentioned the presence of 'Cardita' beaumonti (=Baluchicardia beaumonti) in General Roca rocks. Baluchicardia beaumonti comes from Maastrichtian and Danian beds of northwestern India and Pakistan (Calcaire jaune de la chaine d'Hala, Sind Region), and North Africa (d'Archiac and Haime, 1854; Rutsch, 1936; Heaslip, 1968). According to Fossa Mancini (1938a), this species was mistakenly mentioned by Weaver (1927) because the author followed the ideas of Fritzsche (1919), who synonymized ' $C$.' morganiana with 'C.' beaumonti. Fossa Mancini (1938a) concluded that this synonymy is invalid.

The specimens from the area of General Roca (MLP 15294a-f) were used for erecting the species ' $C$.' burmeisteri (=Kalelia burmeisteri) and 'C.' iheringi (both discussed below) by Böhm (1903).
The only specimens found in Puesto Pircala, Malargüe ('Cardita' morganiana of Behrendsen, 1891 and Burckhardt, 1900) are small internal molds (MLP 10220a-d) with triangular outlines and very rounded margins. The absence of internal characters prevents generic and specific assignment. Casadío (1994) considered them to be juveniles of Venericardia ameghinorum (Ihering, 1907), but Parras et al. (1998) placed them in V. iheringi (Böhm, 1903). Venericardia iheringi is another species based on internal molds, and the Malargüe casts are very similar to this species. In this paper we accept the assignment by Parras et al. (1998), and assign the specimens MLP 10220a-c to 'Venericardia' iheringi.

In this way and according to Fossa Mancini' (1938b), the presence of 'Cardita' morganiana and ' $C$.' beaumonti in Argentina is rejected.

'Venericardia' iheringi (Böhm, 1903).—(Fig. 6.4, 6.5; MLP 15294b-e [Syntypes]; MLP 4298, 5377, 5387, 5517, 5125, 7625, 8866, 8955, 9455, 9726, 10506; MACN-Pi 356; CPBA 6405, 6408; MHNSR:Pi 1010, 1385, 1386, MACN-Pi 5750, MACN-Pi 5754, MACN-Pi 5749, MACN-Pi 5745). As in the previous case, this species was erected by Böhm (1903) based on the internal molds described by Burckhardt (1902, p. 219, figs. 2-6) from General Roca (Danian, Roca Formation). Ihering (1907) included it within Venericardia, but this assignment is not confirmed because this species lacks hinge and external sculpture, the most valuable characters required for a more precise generic placement among carditids. 'Venericardia' iheringi has small to medium-sized shells with subtriangular to subquadrate outlines, rounded margins, prominent and very convex umbones placed subcentrally, and 21-22 radial ribs that are wider than their intercostals spaces. It is distinguished from casts of Kalelia burmeisteri (Böhm, 1903) by its smaller size with more rounded margins and by the absence of an umbonalventral carina. None of the other species from Roca Formation has the set of characters present in ' $V$.' iheringi. Ihering (1907) mentioned a variation of this species, which he named Venericardia iheringi var. boehmi, with a more subquadrate outline, but it is difficult to differentiate from other specimens. Therefore, 'Venericardia' iheringi is a species with uncertain affinities and we cannot assign it to any of the other species described from the Roca Formation.

Venericardia ameghinorum (Ihering, 1907).-(MACN-Pi 340 [Holotype], 5213; CPBA 6406, 6409, 6410, 6412; MLP 5006, 6315, 7285, 7737, 8951, 8956, 10503, 10504, 10505; MHNSR:Pi 1398). Venericardia ameghinorum was erected by Ihering (1907) based on internal molds from General Roca (Roca Formation). This species has elongated shells that are easily distinguishable from other Paleocene carditid species. The elongate outlines with a sinuous ventral margin, and strongly recurved and separated orthogyrous umbones, placed this species within the genus Arca Linnaeus, 1758 (family Arcidae), as already mentioned by del Río et al. (2011).

cf. 'Cyclocardia' sp. (del Río et al., 2007).-(GHUNLPam 22888, 22897-22900). Del Río et al. (2007) described cf. Cyclocardia sp. from the Roca Formation in Cerros Bayos (Danian, La Pampa Province), based on four internal molds of 
articulated individuals. The specimens GHUNLPam 22888 and 22898 have elongate outlines, strongly recurved umbones, and slightly sinuous ventral margin, which placed them within Arca ameghinorum (Ihering, 1907).

The specimens GHUNLPam 22897 and 22899 have more circular outlines, rounded margins, subcentrally placed umbones, and at least 20 radial ribs. Del Río et al. (2007) assigned them tentatively to Cyclocardia Conrad 1867 because of the number of radial ribs and the subcircular outline. 'Venericardia' iheringi Ihering, 1907 has a similar shape, but a less rounded margin, and an identical number of radial ribs. Here, these specimens are placed tentatively with ' $V$.' iheringi.

\section{Discussion}

Previous authors (Ihering, 1907; Fossa Mancini, 1938b) included Paleocene carditids from Argentina in the genus Venericardia Lamarck, 1801. This European taxon is based on Eocene collections from the Paris Basin. Several species ranging from Cretaceous to Recent have been assigned to this genus, but Huber (2010) indicated that Venericardia is an extinct taxon. Although several subgenera have been proposed within Venericardia, a complete systematic and phylogenetic revision is needed. Some of GCP taxa proposed by Heaslip (1968) (species of Claibornicardia, Rotundicardia, and Glyptoactis) were recently reviewed by McClure and Lockwood (2015), who suggested the possible polyphyletic status of each of these genera. The authors explained that the use of few species in their analysis does not permit subgeneric reclassification. In their paper, McClure and Lockwood (2015) excluded Baluchicardia Rutsch and Schenck, 1943 from the analysis because Chavan (1969) included it in the subfamily Carditesine, but Chavan also considered Claibornicardia and Glyptoactis to be members of Carditesinae. In addition, Heaslip (1968) considered Baluchicardia as an alticostate carditid. We consider the polyphyletic status of alticostates and each of alticostate genera in the phylogeny of McClure and Lockwood (2015) to be a consequence of Baluchicardia outgroup status, because this genus is also an alticostate taxa. This analysis needs neither alticostates nor planicostates outgroup for a better evaluation of monophyletic status of these groups. Following the previously mentioned criteria about carditid subgenera, no species of Venericardia sensu stricto were found in Danian assemblages of Argentina. This revision reveals a more diverse generic composition of Paleocene carditid faunas with four different genera that have diverse affinities.

The generic composition of Paleocene Carditidae from Argentina now includes two taxa, Claibornicardia and Rotundicardia, previously reported from the GCP (Fig. 3), and a third genus, Cardites (Fig. 4) that previously was unrecorded from Palaeogene outcrops. The fourth genus, Kalelia n. gen., is a new one related to late Paleocene species from the Paris Basin (Figs. 5, 6.1, 6.2). The North American carditids were previously linked with European Paleogene species (Conrad, 1830; Clark and Martin, 1901; Dall, 1903). Venericor and Claibornicardia species were cited from both regions (Gardner and Bowles, 1939; Verastegui, 1953; Stenzel et al., 1957; Vervoenen and van Nieulande, 2010). Presumed connections previously have been established between these molluscan faunas. For example, Givens (1989) mentioned the volutid gastropod Volutilithes Swainson, 1829 from both regions, and Allmon (1990) proposed phylogenetic relationships between North American and European Eocene nassariid gastropods Bulliopsis Conrad, 1862 and Desorinassa Nuttall and Cooper, 1973. Givens (1989) also indicated several species with European affinities from the Paleogene of the GCP. Del Río and Martínez (2015) recorded GCP members in their Danian bioprovinces. The Rocaguelian and Salamancan bioprovinces of these authors include $12.2 \%$ and $18.8 \%$ of GCP taxa, respectively, and two of the four species described here correspond to these bioprovinces. Claibornicardia paleopatagonica and $R$. mariobrosorum $\mathrm{n}$. sp. comprises GCP elements of the Danian Argentinian molluscan assemblages. To the relationships of this group with the Paris Basin molluscan fauna is the added presence of the genus Kalelia n. gen. in Patagonia. Rotundicardia is a genus that is also represented in the middle Paleocene of Australia (Pebble Point Formation) (Darragh, 1994), but no other Paleocene carditids are present in Australia. The species 'Venericardia' fyfei Finlay and Marwick, 1937 from Wangaloa Formation (Paleocene of New Zealand) was placed tentatively in the genus Purpurocardia Maxwell, 1969 by Maxwell (1969) and Beu and Maxwell (1990), but since ' $V$.' fyfei has some similarities in outline and external sculpture with Claibornicardia species, it could be also placed in this genus. Cardites is not present in others Danian faunas.

The fifth valid taxon included in this work is 'Venericardia' iheringi, which is a species based on casts (Fig. 6.3-6.5). Some internal molds were successfully assigned to $K$. burmeisteri, but in the case of ' $V$.' iheringi there are no characters that allow us to include it in any of the recognized genera. This species is the only carditid found in Maastrichtian rocks (at Puesto Pircala, in Roca Formation). The remaining carditids discussed here are restricted to early Danian beds.

\section{Conclusions}

This study has provided a revision of the Danian Carditidae bivalves from Argentina. During Danian times in Patagonia, the family Carditidae was restricted to four distinctive species representing four genera (Claibornicardia paleopatagonica, Rotundicardia mariobrosorum n. sp., Cardites feruglioi, and Kalelia burmeisteri n. comb.), and one species of uncertain affinities based on internal molds ('Venericardia' iheringi). The first three species constitute the first record of their respective genera from southern South America, and the most ancient record of them. One new species ( $R$. mariobrosorum) is described from Roca Formation. One new genus (Kalelia $\mathrm{n}$. gen.) is described with three species, including $K$. burmeisteri (based so far on internal molds). This revision confirms the biogeographical connections previously established between the Argentinian and North American and Europe carditid Danian faunas (del Río and Martínez, 2015).

\section{Acknowledgments}

The authors are indebted to the curators who facilitated access to collections: M. Longobucco (Museo Argentino de Ciencias Naturales 'Bernardino Rivadavia', Buenos Aires, Argentina), 
M.F. Rodríguez (Servicio Geológico Minero, Argentina), M. Tanuz (Facultad de Ciencias Exactas y Naturales, Buenos Aires, Argentina), M. de La Fuente (Museo de Historia Natural de San Rafael, Argentina), and A. Riccardi (Museo de La Plata, Argentina). We wish to thank J. Sime and P. Callomon (The Academy of Natural Sciences of Philadelphia), L. Cavin (Muséum d'Histoire Naturelle de Genève), and J. Pacaud (Muséum National d'Histoire Naturelle de Paris) for their help with American and European fossil materials. We thank M.S. Vázquez and L. Salgado for their help with field work at Puesto Pircala, and M. Álvarez for his help with photography. We thank M.B. von Baczko and P. Picasso by their language suggestions and we especially acknowledge and thank A. Beu for his invaluable help in polishing the English language, which highly improved the text. We also thank the editor M. Hautmann, the reviewer R. La Perna, and an anonymous reviewer for their constructive comments.

\section{References}

Allmon, W.D., 1990, A review of the Bullia group (Gastropoda: Nassariidae) with comments on its evolution, biogeography and phylogeny: Bulletin of American Paleontology, v. 99, p. 1-179.

Anderson, F.M., 1928, Notes on Lower Tertiary deposits of Colombia and their molluscan and foraminiferal fauna: Proceedings of the California Academy of Sciences (4th Series), 17, p. 1-29.

Barnes, V.E., Hartmann, B.M., and Scranton, D.F., 1992, Geologic Map of Texas, scale 1:500,000: Bureau of Economic Geology: University of Texas, Austin.

Beal, C.H., 1948, Reconnaissance of the geology and oil possibilities of Baja California, Mexico: Geological Society of America Memoirs, v. 31, p. 1-150.

Behrendsen, O., 1891, Zur Geologie des Ostabhanges des argentinischen Kordillere: Zeitschrift der Deutschen Geologischen Gesellschaft, v. 43, p 369-420.

Beu, A.G., and Maxwell, P.A., 1990, Cenozoic Mollusca form New Zealand: Paleontological Bulletin of the New Zealand Geological Survey, v. 58, p. 1-518.

Böhm, J., 1903, Über Ostreen von General Roca am Río Negro: Zeitschrift der Deutschen Geologischen Gesellschaft, v. 55, p. 71-72.

Bruguière, J.G., 1792, Encyclopedie methodique. Tableau encyclopedique et methodique des trois règnes de la nature. Vers, coquilles, mollusques et polypiers: Paris, \& C. H. Agasse, 180 p.

Burckhardt, C., 1900, Perfils geologiques transversaux de la Cordillere argentino-chilienne. Stratigraphie et tectonique: Anales Museo La Plata, Sección Geología y Mineralogía, v. 2, p. 1-136.

Burckhardt, C., 1902, Le gisement supracrétacique de Roca (Río Negro): Revista del Museo de La Plata, v. 10, p. 207-223.

Camacho, H.H., 1992, Algunas consideraciones acerca de la transgresión marina paleocena en la Argentina: Miscelánea de la Academia Nacional de Ciencias, v. 85 , p. $1-41$.

Casadío, S., 1994, Estratigrafía y Paleontología del intervalo MaastrichtianoDaniano en el occidente de la Provincia de La Pampa, Argentina [PhD Thesis]: Córdoba, Facultad de Ciencias Exactas, Físicas y Naturales, Universidad Nacional de Córdoba, $353 \mathrm{p}$.

Casadío, S., 1998, Las ostras del límite Cretácico-Paleógeno de la Cuenca Neuquina (Argentina). Su importancia bioestratigráfica y paleobiogeográfica: Ameghiniana, v. 35, p. 449-471.

Celeste, O., 1940, Relaciones entre el rocaneano y el salamanqueano, en la zona comprendida entre Mamelones de Pinedo, y Vicente Mena y A. Nay en el valle de Río Chico, Chubut [PhD Thesis]: La Plata, Universidad Nacional de La Plata, $56 \mathrm{p}$.

Chavan, A., 1951, Nomenclatural notes on carditids and lucinids: Washington Academy of Science Journal, v. 42, p. 116-122.

Chavan, A., 1969, Superfamily Carditacea Fleming, 1920, in Moore, R.C., ed., Treatise on Invertebrate Paleontology, Pt. N, Mollusca 6, Bivalvia 2: Lawrence, Kansas and Boulder, Colorado, Geological Society of America and University of Kansas Press, p. N491-N518.

Chebli, G., and Serraioto, A., 1974, Nuevas localidades del Paleoceno marino en la región central de la Provincia del Chubut: Revista de la Asociación Geológica Argentina, v. 29, p. 311-318.

Chenu, H.G., 1842, Illustrations conchyliologiques ou description et figures de toutes les coquilles connues vivantes et fossils, classes suivant le système de Lamarck modifie d'aprés les progress de la science et comprenant les genres nouveaux et les espèces récemment découvertes. Tome 10: Paris, Franck, 310 p.
Clark, W.B., and Martin, G.S., 1901, Systematic Paleontology, Eocene, Mollusca, in Maryland Geological Survey, Eocene: Baltimore, The Johns Hopkins Press, p. 122-202.

Collins, L.S., and Coates, A.G., 1999, A paleobiotic survey of Caribbean faunas from the Neogene of the Isthmus of Panama: Bulletins of American Paleontology, v, 357, p. 1-351.

Conrad, T.A., 1830, On the geology and organic remains of a part of the Peninsula of Maryland: Journal of the Academy of Natural Sciences of Philadelphia, v. 6, p. 205-230.

Conrad, T.A., 1833, On some new fossils and recent shell of the United States: American Journal of Science and Arts, v. 23, p. 339-346.

Conrad, T.A., 1838, Fossils of the Tertiary Formations of the United States. Illustrated by figures drawn from nature: Philadelphia, J. Dobson, $80 \mathrm{p}$.

Conrad, T.A., 1862, Descriptions of new genera, subgenera and especies of Tertiary and Recent shells: Journal of the Academy of Natural Sciences of Philadephia, v. 14, p. 284-291.

Conrad, T.A., 1865, Descriptions of new Eocene shells from Enterprise, Mississippi: American Journal of Conchology, v. 1, p. 137-141.

Conrad, T.A., 1867, Description of a new genus of Astartidae: American Journal of Conchology, v. 3, p. 191.

Cope, K.H., Utgaard, J.E., Masters, J.M., and Feldmann, R., 2005, The fauna of the Clayton Formation (Paleocene, Danian) of southern Illinois: a case of $\mathrm{K} / \mathrm{P}$ survivorship and Danian recovery: Bulletin of the Mizunami Fossil Museum, v. 32, p. 97-108.

Cossmann, M., and Peyrot, A., 1912, Conchyliologie neogenique de l'Aquitanie: Pelecypodes: Annales Sociètè linnén Bordeaux, v. 66, p. 121-324.

Cossmann, M., and Pissarro, G., 1904, Iconographia complete des coquilles fossiles de l'Eocene des environs de Paris: Pélécypodes, Tome 1er, Paris, $490 \mathrm{p}$.

Cox, R.L., 1931, The geology of the Farsan Islands, Oizan and Kamaran Island, Red Sea. Part 2. Molluscan palaeontology: Geological Magazine, v. 68, p. $1-18$.

Cox, L., 1941, Lamellibranchs from the White Limestone of Jamaica: Proceedings of the Malacological Society, v. 24, p. 135-141.

Dall, W.H., 1890-1903, Contributions to the Tertiary fauna of Florida with special reference to the Silex Beds of the Caloosahatchie River: Transactions of the Wagner Free Institute of Science of Philadelphia, v. 3, p. $1-1654$.

Dall, W.H., 1902, Synopsis of the Carditacea and of the American species: Proceedings of the Academy Natural Sciences of Philadelphia, v. 54, p. 696-716.

D'Archiac, A., and Haime, J., 1854, Description des animaux fossiles du groupe nummulitique de l'Inde: París, Gide et J. Baudry, 418 p.

Darragh, T.A., 1994, Paleocene bivalves from the Peeble Point Formation, Victoria, Australia: Proceedings of the Royal Society of Victoria, v. 106, p. $71-103$.

Darragh, T.A., and Kendrick, G.W., 2008, Silicified Eocene molluscs from the Lower Murchison district, Southern Carnarvon Basin, Western Australia: Records of the Western Australia Museum, v. 24, p. 217-246.

del Río, C.J., 2012, A new Early Danian gastropod assemblage from northern Patagonia, Río Negro Province, Argentina: Journal of Paleontology, v. 86, p. $47-88$.

del Río, C.J., and Martínez, S., 2015, Paleobiogeography of the Danian molluscan assemblages of Patagonia (Argentina): Palaeogeography, Palaeoclimatology, Palaeoecology, v. 417, p. 274-292.

del Río, C.J., Martínez, S.A., Stilwell, J.D., and Concheyro, G.A., 2007, Palaeontology of the Cerros Bayos section, Roca Formation (Danian), La Pampa Province, Argentina: Alcheringa, v. 31, p. 241-269.

del Río, C.J., Concheyro, G.A., and Martínez, S.A., 2011, The MaastrichtianDanian at General Roca (Patagonia, Argentina): a reappraisal of the chronostratigraphy and biostratigraphy of a type locality: Neues Jahrbuch für Geologie und Paläontologie, Abhandlungen, v. 259, p. 129-156.

Deshayes, G., 1825, Description des coquilles fossiles des environs de París, v. 1, Conchiferes: Paris, published by the author, fasc, v. 2, p. 81-170.

El-Sorogy, A.S., 2002, Paleontology and depositional environments of the Pleistocene coral reefs of the Gulf of Suez, Egypt: Neues Jahrbuch für Geologie und Paläontologie, Abhandlungen, v. 225, p. 337-371.

Farinati, E., Quattrocchio, M., and Labudía, C., 1987, Hallazgo del Maestrichtiano-Terciario fosilífero en el Bajo de Leanza Niyeu y Colan Conhue, Comarca Nordpatagónica, Provincia de Río Negro, Argentina: Actas Décimo Congreso Geológico Argentino, San Miguel de Tucumán, v. 3, p. $153-157$.

Feruglio, E., 1935, Relaciones estratigráficas y faunísticas entre los estratos cretácicos y terciarios en la región del Lago Argentino y en la del golfo de San Jorge (Patagonia): Boletín de Informaciones Petroleras, v. 130, p. 65-100.

Feruglio, E., 1936, Paleontographia Patagónica: Memoria del Instituto Geológico Universidad di Padova, v. 11, p. 1-384.

Férussac, A.E., de, 1822, Tableaux systématiques des animaux mollusques: Paris, Londres, Bertrand, Sowerby, 111 p. 
Finlay, H., and Marwick, J., 1937, The Wangaloan and associated molluscan faunas of Kaitangata-Green Island subdivision: New Zealand Department of Scientific and Industrial Research, Geological Survey Branch, Palaeontological Bulletin, v. 15, p. 1-140.

Fossa Mancini, E., 1938a, La "Cardita Beaumonti" y la "C. morganiana" en la literatura geológica argentina: Notas del Museo de La Plata Tomo 3, Paleontología, v. 14, p. 205-230.

Fossa Mancini, E., 1938b, Las Venericardidae de Malargüe y de Roca en la literatura geológica: Notas del Museo de La Plata, Tomo 3: Paleontología, v. 15 , p. $247-264$.

Freneix, S., Saint Martin, J.-P., and Moissette, P., 1987, Bivalves Hétérodontes du Messinien d'Oranie (Algérie occidentale): Bulletin du Muséum National d'Histoire Naturelle, série 4, v. 9, p. 415-453.

Fritzsche, C., 1919, Eine Fauna aus Schichten der Kreide-Tertiärgrenze in der Argentinischen Cordillere des südlichen Mendoza: Centralblatt für Geologie, Mineralogie und Paläontologie, 359-369.

Gardner, J., 1935, The Midway Group of Texas: The University of Texas Bulletin, v. 3301, p. 1-402.

Gardner, J., and Bowles, E., 1939, The Venericardia planicosta Group in the Gulf Province: United States Geological Survey Professional Paper, v. 189-F, p. 143-215.

Gerth, H., 1935, Geologie Südamerikas 2. Teil: Berlin, Gebrüder Borntráger, 389 p.

Giribet, G., 2008, Bivalvia, in Ponder F.W., and Lindberg D.R., eds., Phylogeny and Evolution of the Mollusca: Berkeley, University of California Press, p. $105-141$.

Givens, C.R., 1989, First record of the Tethyan genus Volutilithes (Gastropoda: Volutidae) in the Paleogene of the Gulf Coastal Plain, with a discussion of Tethyan molluscan assemblages in the Gulf Coastal Plain and Florida: Journal of Paleontology, v. 63, p. 852-856.

Goldfuss, G.A., 1840, Petrefacta Germaniae: Abbildungen und Beschreibungen der Petrefacten Deutschlands und der angränzenden Länder, mi Mitwirkung des Herrn Grafen Georg zu Münster: Leipzig, List und Francke, v. $6,128 \mathrm{p}$.

González, V.L., and Giribet, G., 2014, A multilocus phylogeny of archiheterodont bivalves (Mollusca, Bivalvia, Archiheterodonta): Zoologica Scripta v. 44 , p. $41-58$.

Griffin, M., and Pastorino, G., 2013, Cenozoic Ampullinidae and Naticidae (Mollusca, Gastropoda) from Patagonia, Argentina: Journal of Paleontology, v. 87 , p. $502-525$.

Hanna, M., 1927, An Eocene invertebrate fauna from the La Jolla Quadrangle: University of California Publications, Bulletin of the Department of Geological Sciences, v. 16, p. 247-398.

Harris, G.D., 1895, New and otherwise interesting Tertiary Mollusca from Texas: Proceedings of the Academy of Natural Sciences of Philadelphia, v. 47 p. $45-87$.

Harris, G.D., 1919, Pelecypoda of the Saint Maurice and Claiborne stages: Bulletin of the American Paleontology, v. 6, p. 1-260.

Heaslip, W.G., 1968, Cenozoic evolution of the alticostate venericards in Gulf and East Coastal North America: Palaeontographica Americana, v. 6, p. $55-135$.

Huber, M., 2010, Compendium of bivalves. A full-color guide to 3,300 of the world's marine bivalves. A status on Bivalvia after 250 years of research Hackenheim, Germany, ConchBooks, $901 \mathrm{p}$

Ihering, H. von, 1902, Historia de las ostras argentinas: Anales del Museo Nacional de Historia Natural, v. 2, p. 109-125.

Ihering, H. von, 1903, Les Mollusques des Terrains Crétaciques Supérieurs de 1'Argentine Orientale: Anales del Museo Nacional de Buenos Aires, serie 3, v. 2, p. 193-229.

Ihering, H. von, 1907, Les Mollusques fossiles du Tertiaire et du Crétacé Supérieur de 1' Argentine: Anales del Museo Nacional de Buenos Aires, serie 3, v. 14, p. 1-611.

Ihering, H. von, 1914, Catálogo de Moluscos Cretáceos e Terciarios da Argentina da colleção do autor: Notas Preliminares da Revista do Museo Paulista (São Paulo), v. 1, p. 1-148.

Jimenez, A.P., and Braga, J.C., 1993, Occurrence and taphonomy of bivalves from the Níjar reef (Messinian, Late Miocene, SE Spain): Palaeogeography, Palaeoclimatology, Palaeoecology, v. 102, p. 239-251.

Johnson, C.L., and Graham, S.A., 2007, Middle Tertiary stratigraphic sequences of the San Joaquin Basin, California, in Scheirer, A.H., ed., Petroleum systems and geologic assessment of oil and gas in the San Joaquin Basin Province: California, United States Geological Survey Professional Paper, v. 1713, p. 1-18.

Kafanov, A.I., and Ogasawara, K., 2006, Cenozoic bivalves cenozones of California, Northeastern Pacific: Science Reports Institute of Geoscience of University of Tsukuba, Section B, v. 27, p. 1-12

Kafanov, A.I., Ogasawara, K., and Marincovich, L., 2001, Checklist and bibliography of the Cenozoic marine Bivalvia (Mollusca) of Northeastern Asia (Russian Far East), 1968-1999: Bulletin of the Mizunami Fossil Museum, v. 28, p. 1-138.
La Perna, R., Mandic, O., and Harzhauser, M., 2017, Systematics and palaeobiogeography of Megacardita Sacco in the Neogene of Europe (Bivalvia, Carditidae): Papers in Palaeontology, v. 3, p. 111-150.

Lacour, D., Lauriat-Rage, A., Saint Martin, J-P., Videt, B., Nerandeau, D. Goubert, E., and Bongrain, M., 2002, Les associations de bivalves (Mollusca, Bivalvia) du Messinine du basin de Sorbas (SE Espagne): Geodiversitas, v. 24, p. 641-657.

Lamarck, J.P.B.A. de, 1801, Système des animaux sans vertébres ou tableau général des classes, des orders et des genres de ces animaux: Paris, Déterville, $432 \mathrm{p}$.

Lamarck, J.P.B.A. de, 1806, Suite des mémoires sur les fossiles des environs de Paris: Annales du Muséum National d'Histoire Naturelle, v. 21, p. 53-62.

Lamarck, J.P.B.A. de, 1819, Histoire naturelle des animaux sans vertèbres, v. 6 : Paris, published by the author, $232 \mathrm{p}$.

Lamy, E., 1921, Révision des Carditacea vivants du Muséum National d'Histoire Naturelle de Paris: Journal of Conchyliology, v. 66, p. 218-276.

Lea, I., 1833, Contributions to Geology. 1-Tertiary Formations of Alabama: Philadelphia, Carey, Lea and Blanchard publishers, p. 9-187.

Link, H.F., 1807, Beschreibung der Naturalien-Sammlung der Universität zu Rostock: Rostock, Adlers Erben, pt. 4, 30 p.

Linnaeus, C., 1758, Systema naturae per regna tria naturae, secundum classes, ordines, genera, species, cum characteribus \& differentiis. Editio decima, reformata. Tom. I: Holmiae, Laurentii Salvii, 824 p.

Lhomme, V., and Freneix, S., 1993, Un coquillage de bivalve du Maastrichtienpaléocène Glyptoactis (Baluchicardia) sp. dans la couche inférieure du gisement moustérien de "Chez-Pourré-Chez-Comte" (Corrèze): Bulletin de la Société Préhistorique Française, v. 90, p 303-306.

Masiuk, V., 1967, Estratigrafía del Rocanense del Puesto Alvarez, curso inferior del río Chico, Provincia del Chubut: Revista del Museo de La Plata, n.s. Sección Paleontología, v. 5, p 197-258.

Maxwell, P., 1969, Middle Tertiary Mollusca from North Otago and South Canterbury, New Zealand: Transactions of the Royal Society of New Zealand, Geology, v. 6, p. 155-185.

McClure, K., 2009, Phylogenetic relationships and morphological changes in Venericardia on the Gulf Coastal Plain during the Paleogene [Undergraduate Honors Thesis]: Williamsburg, Virginia, The College of William and Mary, 157 p. http://publish.wm.edu/honorstheses/297.

McClure, K., and Lockwood, R., 2015, Relationships among Venericardia (Bivalvia: Carditidae) on the U.S. Coastal Plain during the Paleogene: Journal of Paleontology, v. 89, p. 522-531.

McNamara, K.J., and Kendrick, G.W., 1994, Cenozoic Molluscs and Echinoids of Barrow Island, Western Australia: Records of the Western Australian Museum Supplement, v. 51, p. 1-50.

Medina, F.A., Camacho, H.H., and Malagnino, E.C., 1990, Bioestratigrafía del Cretácico Superior-Paleoceno marino de la Formación Lefipán, Barranca de los Perros, Río Chubut, Chubut: Actas del $5^{\circ}$ Congreso Argentino de Paleontología y Bioestratigrafía, Tucumán, v. 1, p. 137-142.

Menesini, E., and Ughi, R., 1982, I molluschi del giacimento di Vallebiaia: $1^{\circ}$ Parte - Lamellibranchi: Geologica Romana, v. 21, p. 733-747.

Meyer, O., 1885, The genealogy and the age of the species in the Southern Old-Tertiary: The American Journal of Science, series 3, v. 29, p. 457-468

Meyer, O., and Aldrich, T.H., 1886, The Tertiary fauna of Newton and Wautubbee, Mississippi: The Journal of Cincinnati Society of Natural History, v. 9, p. 40-50.

Moore, E.J., 1992, Tertiary marine pelecypods of California and Baja California: Erycinidae through Carditidae: U.S. Geological Survey, Professional Paper 1228-E, p. 1-37.

Nuttall, C.P., and Cooper, J., 1973, A review of some English Palaeogene Nassaridae, formerly referred to Cominella: British Museum (Natura History) Geology Bulletin, v. 23, p. 179-219.

Olsson, A.A., 1941, A Pliocene fauna from Western Ecuador: Proceedings of the Natural Sciences of Philadelphia, v. 93, p. 1-79.

Olsson, A.A., 1964, Neogene Mollusks from Northwestern Ecuador: Ithaca, New York, Paleontological Research Institution, $256 \mathrm{p}$.

Pacaud, J-M., and Le Renard, J., 1995, Révision des mollusques paléogènes du Bassin de Paris IV—Liste systématique actualisée: Cossmanniana, v. 3, p. $151-187$.

Palmer, K.V.W., and Brann, D.C., 1965, Catalogue of the Paleocene and Eocene Mollusca of the Southern and Eastern United States. Part I. Pelecypoda, Amphineura, Pteropoda, Scaphopoda, and Cephalopoda: Bulletins of American Paleontology, v. 48, p. 1-467.

Parodiz, J.J., 1996, The taxa of fossil mollusca introduced by Hermann von Ihering: Annals of Carnegie Museum, v. 65, p. 183-296.

Parras, A.M., Casadío, S., and Candela, M., 1998, Seceuncias deposicionales del Grupo Malargüe y el límite Cretácico-Paleógeno en el sur de la provincia de Mendoza, Argentina: Asociación Paleontológica Argentina, Publicación Especial, v. 5, p. 61-69.

Penna, L., 1965, Formaçao Maria Farinha (Paleoceno), estado de Pernambuco, Brasil: Malacofauna e consideracoes paleoecologicas: Papeis Avulsos do Departamento de Zoologia, v. 17, p. 259-276. 
Pérez, D.E., and del Río, C.J., 2016, Phylogeny of Carditidae (Bivalvia: Archiheterodonta): revisiting the subfamiliar systematic scheme: $35^{\circ}$ Annual Meeting of the Willi Hennig Society, Abstracts Book, p. 54.

Petersen, C.S., 1946, Estudios geológicos en la región del río Chubut Medio: Boletín de la Dirección General de Minas y Geología, v. 59, p. 1-137.

Rathbun, R., 1875, Preliminary report on the Cretaceous lamelibranchs in the vicinity of Pernambuco, Brazil: Proceedings of the Boston Society of Natural History, v. 17, p. 241-256.

Reeve, L.A., 1843, Conchologia Iconica, v. 1: London, L. Reeve \& Co., 608 p.

Rodríguez, M.F., Getino, P.R., and Sepúlveda, E.G., 1995, Elementos faunísticos del Cretácico-Terciario marino en el Rincón de Colitoro Grande, provincia de Río Negro: $6^{\circ}$ Congreso Argentino de Paleontología y Bioestratigrafía, Trelew, Actas, p. 239-246.

Rutsch, R., 1936, Beiträge zur Kenntnis tropisch-amerikanischer Tertiärmollusken. 5. Ist Venericardia beaumonti auf die Oberkreide beschränkt? Eclogae Geologische Helvetiae, v. 29, p. 187-207.

Rutsch, R., 1943, Die Paläocän-Mollusken der Inseln Trinidad und Soldado Rock (Britisch-Westindien): Ecoglae Geologicae Helvetiae, v. 36, p. 139-191.

Rutsch, R., and Schenck, H, 1943, in Rutsch, R., ed., Die Paläocän-Mollusken der Inseln Trinidad und Soldado Rock (Britisch-Westindien): Ecoglae Geologicae Helvetiae, v. 36, p. 139-191.

Sacco, F., 1899, I Molluschi dei terreni terziarii del Piemonti e della Liguria. Parte XXVII (Unionidae, Carditidae, Astartidae, Crassatellidae, Lasaeidae, Galeommidae, Cardiidae, Limnocardiidae e Chamidae): Turin, Carlo Clausen, 102 p.

Scasso, R.A., Aberhan, M., Ruiz, L., Weidemeyer, S., Medina, F.A., and Kiessling, W., 2012, Integrated bio- and lithofacies analysis of coarse-grained, tide-dominated deltaic environments across the Cretaceous/Paleogene boundary in Patagonia, Argentina: Cretaceous Research, v. 36, p. 37-57.

Sieber, R., von, 1954, Die Mittelmiozänen Carditidae und Cardiidae des Wiener Beckens: Mitteilungen der Geologischen Geselischaft in Wien, v. 47, p. $183-234$.

Sowerby, G.B., I., 1833, New species of shells from the collection formed by Mr. Cuming on the western coast of South America, and among the islands of the South Pacific Ocean: Proceedings of the Zoological Society of London, v. 1, p. 16-22.

Sowerby, J., 1821, Mineral Conchology of Great Britain; or, coloured figures and descriptions of those remains of testaceous animals or shells, which have been preserved at various times and depths in the earth: London, Richard Taylor, v. 3, 202 p.

Stanley, S.M., 1972, Functional morphology and evolution of byssally attached bivalve mollusks: Journal of Paleontology, v. 46, p. 165-212.

Stenzel, H.B., and Krause, E.K., 1957, in, Stenzel, H.B., Krause, E.K., and Twining, S.T., Pelecypoda from the type locality of the Stone City beds (Middle Eocene) of Texas: University of Texas Publication, v. 5704, p. 1-237.

Stewart, R.B., 1930, Gabb's California Cretaceous and Tertiary type Lamellibranchs: Special Publication of the Academy of Natural Sciences of Philadelphia, v. 3, p. 1-314.

Stilwell, J.D., 2003, Patterns of biodiversity and faunal rebound following the K-T boundary extintion event in Austral Paleocene molluscan faunas: Palaeogeography, Palaeoclimatoly, Palaeoecology, v. 195, p. 319-356.
Swainson, W., 1829, Zoological Illustrations. Second Series: London, Baldwin \& Cradock, v. 1, 279 p.

Tate, R., 1886, The lamellibranchs of the older Tertiary of Australia. Part I: Transactions and Proceedings of the Royal Society of South Australia, v. 8 , p. $96-158$

Tavora, V., Rodrigues Dos Santos, A.A., and Araújo, R.N., 2010, Localidades fosilíferas da Formaçao Pirabas (Mioceno Inferior): Boletin Museu Pará Emilio Goeldi. Ciencias Naturales, Belém, v. 5, p. 207-224.

Tracey, S., Todd, J. A., Le Renard, J., King, C., and Goodchild, M., 1996, Distribution of Mollusca in Units S1 to S9 of the Selsey Formation (middle Lutetian), Selsey Peninsula, West Sussex: Tertiary Research, v. 16, p. $97-139$.

Verastegui, P., 1953, The pelecypod genus Venericardia in the Paleocene and Eocene of Western North America: Paleontographica Americana, v. 3, p. $1-112$.

Vervoenen, M., and van Nieulande, F.A.D., 2010, Claibornicardia aalterensis n. sp., a new carditid species from the Eocene of Southern North Sea Basin: Cainozoic Research, v. 7, p. 79-81.

Vigilante, S.L., 1977, Bioestratigrafía de la Formación Salamanca, Cuenca del Golfo San Jorge, Provincia del Chubut [Msc Thesis]: Buenos Aires, Facultad de Ciencias Exactas y Naturales, Universidad de Buenos Aires, $36 \mathrm{p}$.

Vokes, H.E., 1939, Molluscan faunas of the Domengine and Arroyo Hondo Formations of the California Eocene: Annals of the New York Academy of Sciences, v. 38 , p. 1-246.

Weaver, C.E., 1927, The Roca Formation in Argentina: American Journal of Science, series 5, v. 12, p. 417-434.

Weaver, C.E., 1931, Paleontology of the Jurassic and Cretaceous of West Central Argentina: University of Washington, Memoir, v. 1, p. 1-469.

White, C.A., 1887, Contribuiçoes á Paleontologia do Brasil: Arquivos do Museu Nacional do Río de Janeiro, v. 7, p. 1-273.

Whitfield, R.P., 1885, Brachiopoda and Lamellibranchiata of the Raritan clays and green-sand marls of New Jersey: United States Geological Survey Monograph, v. 9, p. 1-338.

Wilckens, O., 1905, Die Lamellibranchiaten, Gastropoden, etc. der oberen Kriede Südpatagoniens: Berichten der Naturforschenden Gessellschaft zu Freiburg im Breisgau, v. 15, p. 91-156.

Windhausen, A., 1918, Rasgos de la historia geológica de la planicie costanera en la Patagonia septentrional: Boletín de la Academia Nacional de Ciencias de Córdoba, v. 23, p. 319-364.

Windhausen, A., 1931, Geología Argentina. Geología histórica y regional del territorio argentino, Segunda Parte: Buenos Aires, Peuser, 645 p.

Wood, S.V., 1861, A monograph of the Eocene bivalves of England: London, J. K. Adland, Bartholomew Close, v. 1, 182 p.

Woodring, W.P., 1982, Geology and Paleontology of Canal Zone and adjoining parts of Panama. Description of Tertiary Mollusks: Professional Papers of the United States Geological Survey, v. 306 F, p. 1-759.

Accepted 21 June 2017 